Historic, Archive Document

Do not assume content reflects current scientific knowledge, policies, or practices. 
+ 

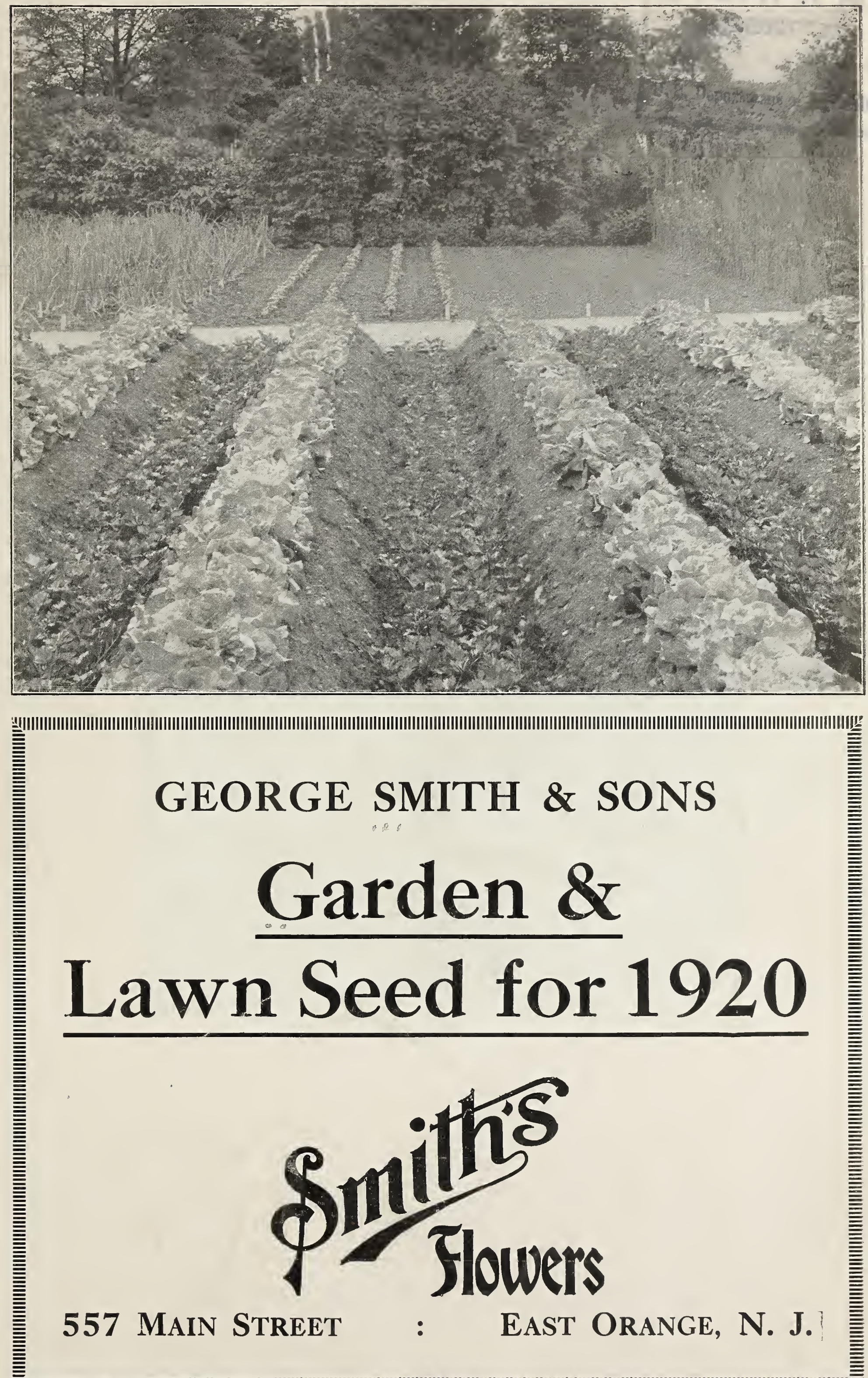


\section{Success in the Garden}

\section{Means (1) Good Soil; (2) Good Seed; (3) Your Co-operation}

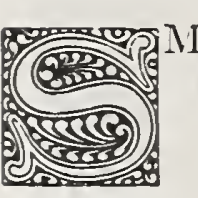
IITH'S GARDEN SEEDS are just as good as Smith's flowers. They have been tested for
germination and purity; they have proved to our entire satisfaction that they will produce bumper crops of true-to-name flowers and vegetables. We have been selling seed of this high character in this community for many years, and our business has grown from a very small beginning to such proportions that we are a useful factor in this locality. People have come to us year after year for their seed; we have helped them obtain large crops and prosper. Our reputation for fair dealing and reliable stock is back of our invitation to you to make this store your headquarters for whatever seeds or supplies of a horticultural or agricultural nature you may need. We carry a full line of such supplies and are ready, in addition, to give advice as to what, when, and how to plant.
Good soil is an important factor; if your particular soil needs building up, we have the proper fertilizers with which to do it. Good seed is essential; we have it ready for you. Come to think of it, your co-opera- tion is the only other element in a successful garden that really figures. We have the supplies and the willingness to serve you. If you will co-operate, success in your garden, barring unfavorable conditions beyond human control, is assured.

\section{Have an Old-Fashioned Flower-Garden}

" Revive interest in your community in the old-fashioned garden that was such an intimate part of Grandmother's life - the richly colored, sweetly fragrant, altogether charming plants that "come back" each Spring with renewed vigor and fresh beauty. Have such a garden this year.1. See page 12 for a suggested list of plants to choose from in planning such a delightful place.

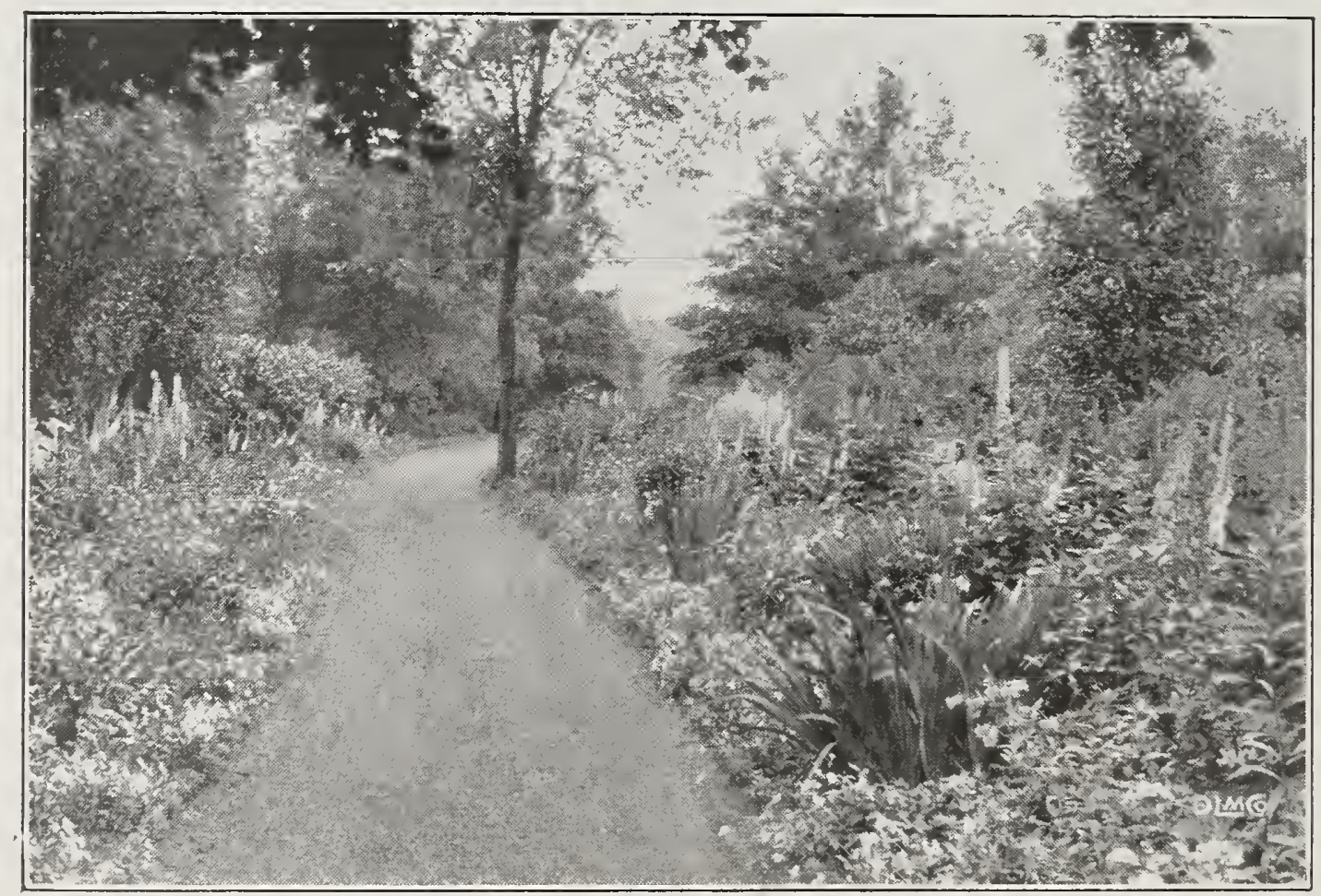

\section{Concerning Prices}

The prices quoted on the following pages do not include free delivery except for seeds in packets, ounces, or quarter-pounds, on which we prepay postage.

All prices in this Catalogue are subject to change without notice.

Non-Warranty George Smith \& Sons give no warranty, express or implied, as to description, send out, and they will not be in any way responsible for the crop. If the purchaser does not accept the goods on these terms, they are at once to be returned.

\section{GEORGE SMITH \& SONS}




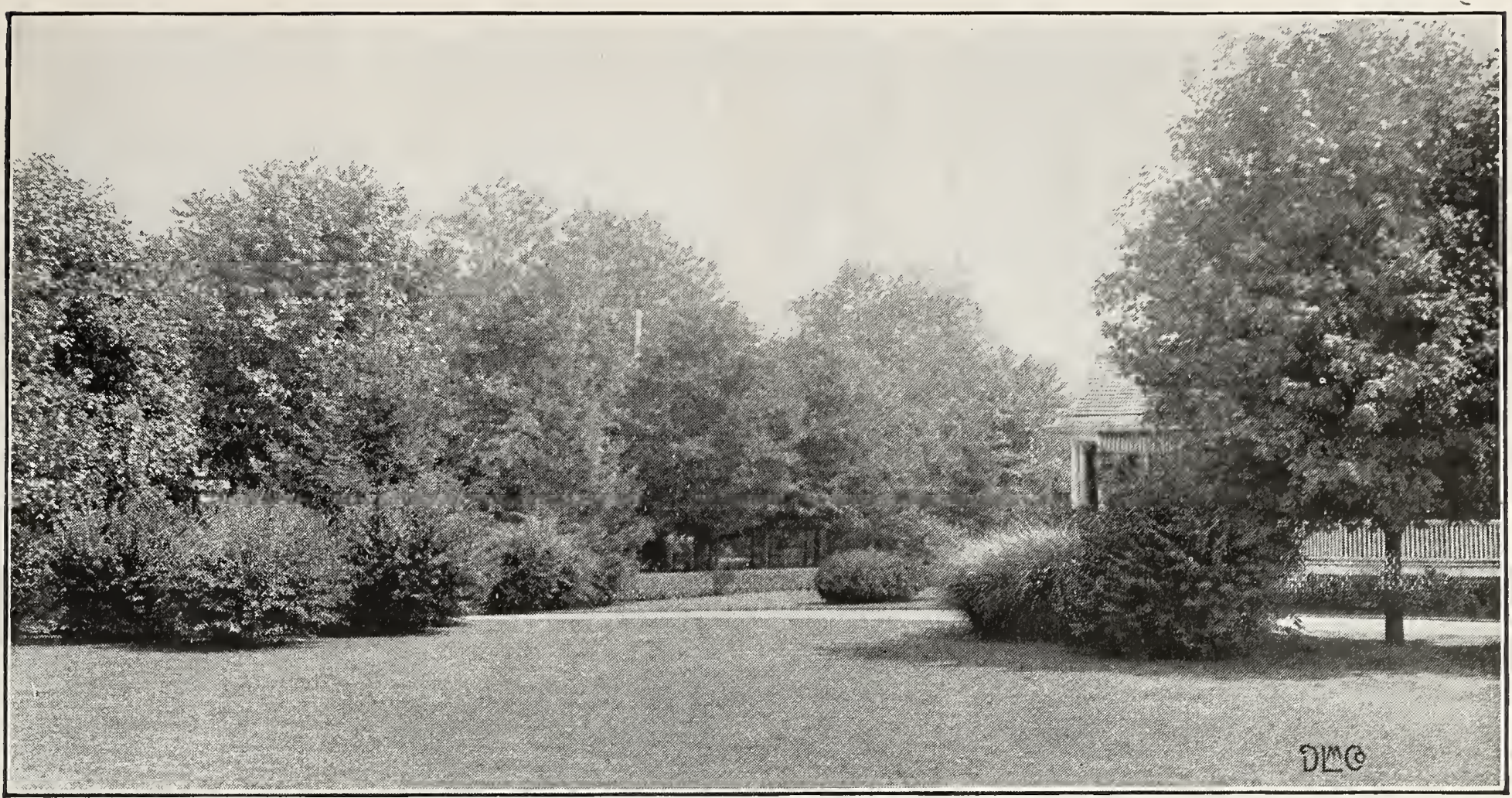

\section{Lawn Grass Seed}

\section{Smith's Bowling-Green Grass Seed Mixture}

Bowling on the green (a Scotch game) is little known in this country. It is played on a perfectly level green, 120 feet square, seeded with the finest grass seed. Naturally, such a green is subjected to a great deal of abuse.

Sixteen years ago we laid down the Seven Oaks Bowling-Green, at Orange, N. J., a green that has stood the test of bowling from early Spring until late Fall in the intervening years. The green is as fine a piece of grass as can be found anywhere in the country. In planning for it, we consulted many grass experts and experimented with many mixtures before finally deciding on the one which we have named 'Smith's Bowling-Green Grass Seed Mixture," a combination of grass seeds that is unsurpassed for making new or renovating old lawns. $1 / 2$ lb. 30 cts., lb. 60 cts., 5 lbs. $\$ 2.00,11$ lbs. (1/2 bus.) $\$ 3.75,22$ lbs. (bus.) $\$ 7.00$.

\section{Shady Spot Lawn Grass Mixture}

A combination of grasses that has been especially selected because of the sturdy, sure growth in shady places, where it is usually difficult to obtain a satisfactory growth. $1 / 2$ lb. 35 cts., lb. 70 cts., 5 lbs. $\$ 2.50$, 12 lbs. ( $1 / 2$ bus.) $\$ 4.50,24$ los. (bus.) $\$ 8.00$.

\section{Special Grass Mixture}

For such places as terraces, tennis-courts, golf-links or seaside planting, we have mixtures of grass seeds that have been made up with the special needs of the places mentioned in mind. Write for prices on these special mixtures.

\section{Grasses for Permanent Pastures}

We have first-class stocks of the seeds named below and will be glad to have you get our prices before buying elsewhere.

Kentucky Bhlue Grass. One of the most widely distributed and valuable native grasses. It is a true perennial, lasting indefinitely and improving each year.

Hard Fescue. A hardy grass for dry land ; especially valuable for permanent pastures.

Meadow Fescue. Is very nourishing, either green or dry, and is much relished by cattle.

orchard Grass. Stock of all kinds are very fond of this grass, and it endures a constant cropping better than any other.

Perennial Rye Grass. Cures into hay having a sweet flavor; much relished by horses and cattle. Nutritive value very great.
IRed-Top. A very lardy native perennial grass, succeeding best on moist land.

Rhode Island Bent. Resembles Red-Top. but is of dwarfer habit, with shorter, narrower leaves. Makes a beautiful, close, fine turf.

Sheop Fescue. Though of dwarf growth, it grows thickly, yielding a large amount of nutritious herbage.

Ta!l Oal Grass. Makes an early and luxuriant growth; relished by cattle early and late.

Timothy. The most important of the hay grasses; very nourishing. and can be preserved a long time.

While Clover. Dwarf, spreads rapidly, and is very hardy. Sweet and nutritious. 


\section{Vegetable Seeds}

\section{Beans, Dwarf or Bush}

Culture.-Beans are somewhat tender, but it is sometimes worth while to take chances with the weather so as to have harrest a few dars earlier. For a regular crop, however, plant in loamy soil at the beginning of settled warm weather, and at intervals for succession until August. Rows may be made 2 feet apart. and the Beans planted a few inches apart in the drills. or three or four Beans in hills 1 or $S$ inches apart. One quart will plant a row 100 feet long: about one and one-half bushels to the acre. Cultivate and hoe frequently, always, however, when the vines are perfectly dry.

Black Valenline. In early, hardy variety, producing an abundance of straight, round, dark green pods which ripen a few dars later than Early Red Valentine. Plit. 15 cts., pt. 40 cts., qt. 75 cts. 4 qts. $\$ 2.75$.

Bountiful. Extra early; ready for market six weeks from planting. An enormous yielder. Long, flat, stringless pods; quality very fine. Pkt. 15 cts., pt. 40 cts., qt. 70 cts., 4 qts. $\$ 2.70$.

Iroston Pea or Navy. More prolific than the common white Bean, of better quality, and a snre cropper Much used for baked Beans. Pkt. 15 cts., pt. 35 cts., qt. 70 cts.. 4 qts. $\$ 2.70$.

Longfellow. Long, straight, round, solid green pods; very early. Pkt. 15 cts., pt. 35 cts., qt. 70 cts., 4 qts. $\$ 2.70$.

Early Red Valentine. Extra early; about fifty days from planting to picking. Round-podded; of good quality and fine flavor. Pkt. 15 cts., pt. 40 cts.. qt. 75 cts., 4 qts. $\$ 2.80$.

Long Yellow Six Weelis. A well-known variety that is grown mostly for market. Pkt. 15 cts., pt. 40 cts., qt. 70 ets., 4 qts. $\$ 2.70$.

Refugec, or 1000-to-1. Rather late grower, taking about seventy days to reach maturity. A great favorite for canning purposes. Plants 15 to 18 inches high, very productive of long. round, green-podded Beans, which are meaty and very tender. Plst. 15c., pt. 35c., qt. 70c., 4 qts. $\$ 2.70$.

Giant Stringless Green-Pod. Extra early, ready for picking forty-five days from planting. A great favorite of market gardeners everywhere. Romnd pods of fine quality and flavor; absolutely stringless. Pkt. 15c.. pt. 35c., qt. 70c., 4 qts. $\$ 2.70$.

\section{Beans, Dwarf Wax-Podded}

Black Wax. Very early, enormously productive, and of fine quality. Pods of medinm length, creamy yellow, quite round, very thick-fleshed, and tender. Pkt. 15c., pt. 40c.. qt. $80 \mathrm{c} ., 4$ qts. $\$ 3.00$.

Currie's Rust-Proof Wax. A mid-season variety of finest quality. Pods long, flat and very tender. Pkt. 15c., pt. 40c., qt. S0c., 4 qts. $\$ 3.00$.

Golden-Eye Wax. Extremely vigorous, free from blight, and a heavy cropper. Pods clear creamy white, very long. flat, but fleshy, stringless, and of good quality. Plit. 15c., pt. 40c., qt. S0c., $4 \mathrm{qts}$. $\$ 3.00$.

Improved Golden Wax. Early, maturing in fifty days. Pods 4 to 5 inches long, half-round, stringless, and of excellent quality. Plit. 15c., pt. 40c., qt. $75 \mathrm{c} ., 4$ qts. $\$ 2.80$.

Hodson Wax. Handsome. thick, flat, yellow pods. Heavy bearer. Pkt. 15c., pt. 40c., qt. S0c., 4 qts. $\$ 3.00$.

Davis' While Kidney Wax. Long. waxy, white, flat pods. Pkt. 15c., pt. 40c., qt. S0c., 4 qts. $\$ 3.00$

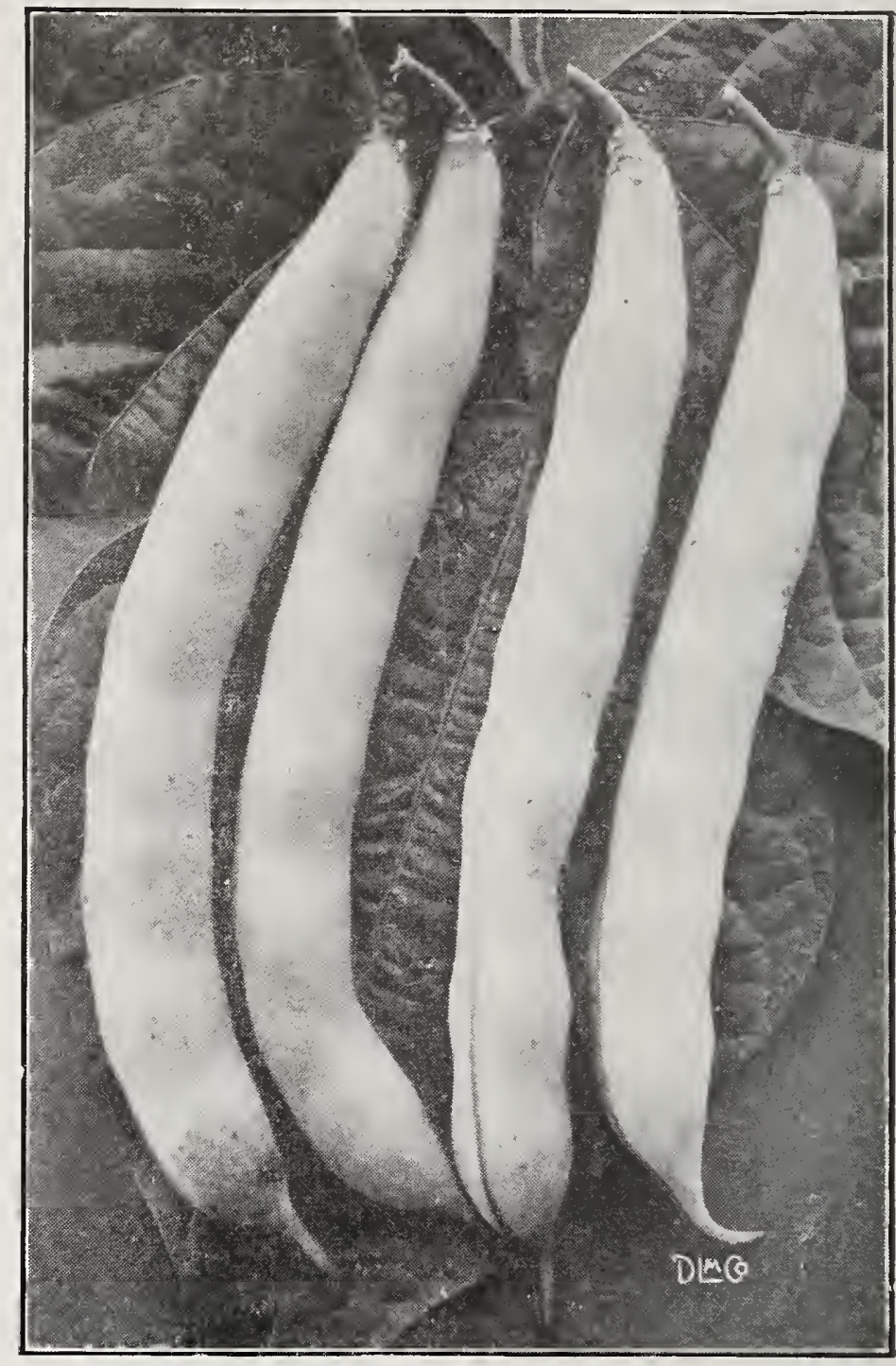

\section{Stringless Green-Pod Beans \\ Beans, Bush Lima}

Culture.-Make the rows 2 feet apart and give each plant 12 inches of space. If the soil becomes hard or crusted, keep it broken up, or your Limas will never come through. Wait until the soil is warm (about May 15) before planting. One quart will plant 150 hills; twelve to sixteen quarts to the acre. Plant seed with the eye down.

Burpee's Bush Lima. A very popular variety, with splendid, branching. circular bushes 18 to 20 inches high and 2 to 3 feet across. Pkt $15 \mathrm{c}$. pt. 50c., qt. $90 \mathrm{c} ., 4 \mathrm{qts}$. $\$ 3.40$.

Dreer's Bush Lima. Produce pods in great abundance. The sweet and succulent seeds are thickly crowded in the pods. Pkt. 15c., pt. 60c., qt. $\$ 1.00,4$ qts. $\$ 3.50$.

Fordhook Bush Lima. Pods larger than the Dreer's and six to eight days earlier. Beans thick and meaty, four to a pod, tender. juic $y$, and of fine flavor. A heavy yielder. Plit. 15c.. pt. 60c.. nt. $\$ 1.00,4$ qts. $\$ 3.50$

\section{Beans, Pole Lima}

Culture.-The Pole Limas need warm weather, and a well-manured sandy soil. Set poles in rows 4 feet apart, the poles being abont 3 feet apart in the row. In the hill around each pole, plant five or six Beans, placing them 2 inches deep, on edge, with the eye down. and firm the soil over them. When the plants are well started, thin out, leaving he four strongest plants to each hill.

Challenger. An early variety of excellent quality and great productiveness. Pods average 3 to 4 inches long, each containing three to five thick Beans of fine flavor, which cook rich and mealy. Pkt. $15 \mathrm{c} .$, pt. $45 \mathrm{c}$. , qt. 90c., 4 qts. $\$ 3.40$. 
BEANS, POLE LIMA-Continued

Early Jersey Lima. This variety is ten days earlier than the ordinary variety, while it is equal in flavor and productiveness. Pkt. 15c., pt. $45 \mathrm{c} .$, qt. $90 \mathrm{c} ., 4$ qts., $\$ 3.40$.

King of the Garden. A prolific, early-bearing sort that produces large flat pods of good quality containing five or six large Beans. Pkt. 15c., pt. $45 \mathrm{c}$. qt. $90 \mathrm{c} ., 4$ qts. $\$ 3.40$.

Large White Lima. Very largely grown for family use. The large, flat, kidney-shaped Beans are tender and delicious when cooked. Pkt. 15c., pt. $45 \mathrm{c} .$, qt. $90 \mathrm{c} ., 4$ qts. $\$ 3.40$.

\section{Beans, Pole or Running}

Culture.-Practically the same as for Pole Lima Beans. Be sure that the ground is warm and mellow. for. if planted in cold, wet ground, the seed will rot.

Horticultural Dwarf. Good as a shell Bean, either green or dry. Pods long, round and thick, freely produced. Beans large, spotted with red; of good flavor. Pkt. 15c., pt. 40c., qt. 75c., it qts. $\$ 2.90$.

Kentucky Wonder or old Homestead. Pods a silvery green color, large, and tender; borne in clusters. Pkt. 15c., pt. 40c., qt. $75 \mathrm{c} ., 4$ qts. $\$ 2.75$.

Lazy Wife. Broad, thick, fleshy, green pods that are entirely stringless. Pods average 6 inches long and are borne in great abundance. The white Beans may be used as soup Beans if allowed to dry in the pods. Pkt. 15c., pt. $40 \mathrm{c}$., qt. $75 \mathrm{c} ., 4$ qts. $\$ 2.90$

Scarlet Runner. Very ornamental in the garden with its bright scarlet flowers. Good as a snap or shell Bean. Plit. 15c., pt. 40c., qt. 75c., 4 qts. $\$ 2.90$.

\section{Beets}

Culture-For good Beet crops, plant in fibrous loam, well drained and well enriched. For early table Beets, have drills 16 to 20 inches apart, and sow the seed about 1 . inch deep as early as the ground can be put in good condition; or, seed may be sown under glass four weeks earlier and the young seedlings transplanted to open ground to give an extra-early crop. Give thorough and clean cultivation and thin the plants to stand 3 to 4 inches apart in the rows. For succession, sow at intervals until the middle of July. One ounce will sow 50 feet of drill; five to six pounds to the acre. Crimson Globe. A second-early variety, of medium size and good shape; flesh and skin are both very dark; sweet and tender. Pkt. 10c., oz. 25c., $1 / 4$ lb. $75 \mathrm{c}$., lb. $\$ 2.50$.

Crosby's Extra-Early Egyptian. An improved strain of the old Extra-Early Egyptian, with round, somewhat flat shape; flesh bright vermilion-red, of finest quality and flavor. Pkt. 10c., oz. 25 c., $1 / 4$ lb. 75 c., lb. $\$ 2.50$.

Early Blood Turnip. A handsome, smooth, dark red Beet that is early and also good for summer and autumn use. Pkt. 10c., oz. 25c., 1/4 1b. 70c., lb. $\$ 2.25$.

Eclipse. An extremely early, rapid-growing variety of small size. Round, smooth, deep red, and of very fine quality. Pkt. 10c., 0z. 25c., 1/4 lb. 65c.. 1b. $\$ 2.00$

Detroit Dark Red. Round; skin dark blood-red; flesh bright red. Pkt. 10c., oz. $25 \mathrm{c} ., 1 / 4 \mathrm{lb} .75 \mathrm{c}$, lb. $\$ 2.50$

Extra-Early Egyptian. An early variety suitable for forcing and growing in the open garden. Roots rich, dark crimson, with very small taproots; flesh dark blood-red, zoned with lighter shade; crisp, sweet; very desirable. Pkt. 10c., oz. $25 \mathrm{c} .{ }^{1 / 4}$ lb. $75 \mathrm{c} ., \mathrm{lb} . \$ 2.50$.

Half-Long Blood, Winter. A half-long Beet of the finest quality; sweet. crisn and tender. Plit. $10 \mathrm{c} .$, oz. 25c., $1 / 4$ lb. $75 \mathrm{c}$. . 1b. $\$ 2.50$.

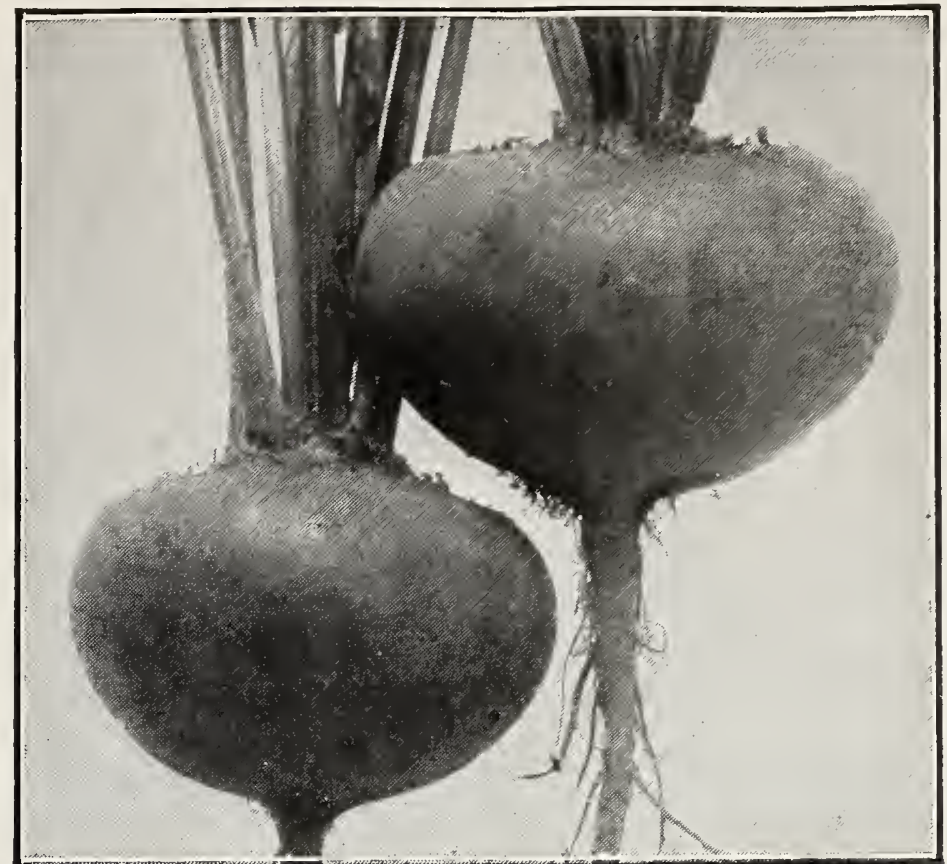

Crosby's Extra Early Egyptian

BEETS-Continued

Market-Gardeners'. 'The great all-season Beet. Makes a rapid growth and heavy root, for autumn or winter use. Deep red, sweet and very crisp. Keeps well and appeals very strongly to everybody wanting a first-class, all-seasons, table Beet. Pkt. 10c., oz. 20c., 1/4 lb. 60c., lb. $\$ 2.00$.

New Early Model. Early ; smooth. very dark red sort. A splendid variety. Plit. 10c., oz. 25c., 1/4 lb. 65 c., lb. $\$ 2.00$.

\section{Swiss Chard}

Common. A close relative of the Beets, grown for the succulent leaves which are prepared for the table like spinach. Pkt. 10c., oz. 25c., $1 / 4 \mathrm{lb}$. $60 \mathrm{c}$. lb. $\$ 2.00$.

Luculius. The large leaves of this variety are unusually crimped and curled, somewhat resembling the Savoy-leaved cabbage. The midribs are cooked like asparagus. the leafy part like spinach. Pkt. 10c., oz. 30c., 1/4 lb. T5c., lb. $\$ 2.50$.

\section{Mangel-Wurzel}

Culture.-In May or June, sow the seed in drills not less than 2 feet apart. and later thin out so the plants stand from 6 to 8 inches apart in the row. As they grow to an immense size. a deep soil that has been well enriched with stable manure is best suited for their culture. Six pounds will sow an acre.

Mammoth Long Red. A standard sort that yields great crops of long, straight, thick roots having light red flesh. Highly prized for feeding stock during the winter months. $1 / 4$ lb. $40 \mathrm{c}$., lb. $\$ 1.15$, $10 \mathrm{lbs}$. or over $\$ 1.00$ per $\mathrm{lb}$.

Yellow Globe. $1 / 4$ lb. $40 \mathrm{c}$., lb. $\$ 1.15,10 \mathrm{lbs}$. or over $\$ 1.00$ per $1 b$.

Sugar Beets, Giant Rose IIalf Sugar. 1/4 lb. $50 \mathrm{c}$., lb. $\$ 1.50$.

\section{Brussels Sprouts}

Culture.-For early fall use, sow seed outloors in May, and during. July set plants every 18 inches in rows 2 feet apart. Later sowings may be made in June. One ounce of seed will produce about 3.000 plants.

Improved IIalf-Dwarf. Early and dwarf-growing: large, tender heads. Pkt. 10c., 1/2 oz. 30c., oz. $50 \mathrm{c}$. . $1 / 4$ lb. $\$ 1.50$. 


\section{Cauliflower}

Culture.--Same as for cabbage, only Cauliflower requires richer soil and more care while growing. When the heads begin to form, tie the leares up over the head to prevent discoloring by sum and rain.

Aulumn Giant. Vigorous-growing late sort, forming very large heads Plst. 30c., 1/4 oz. $75 \mathrm{c} ., 1 / 2$ oz. $\$ 1.50$, oz. $\$ 3.00$.

Early Snowball. One of the earliest and most reliable sorts. Dwarf and compact, with few small outer leaves. Fine for the home garden. I'kt. 85c.. 1/4 oz. \$1.75, 1/\% oz. \$3 00, oz. $\$ .5 .00$

Earliest Dwarf Erfurl. 'The best and earliest for forcing under glass; dwarf. compact. small leaves. Pkt. 50c., 1/4 oz. $\$ 2.50$, oz. $\$ \$ .00$.

\section{Chicory}

Sow in early spring in good mellow soil in drills $1 / 2$ inch deep and 12 inches apart. The roots will be ready to dig in autumn; when dried. are used as an adulterant for coffee. The roung leaves are excellent as a salad. Pkt. 10c.. oz. $50 \mathrm{c}$., 1/4 lb. $\$ 1.75$.

\section{Cabbage}

Culture.-Rich loam, with a gravelly subsoil. is best soil for Cabbage growing. although almost any piece of land will do if properly prepared. Commence to sow seed early for a succession. Transplant. as soon as large enough, to fresh, rich soil, in rows 2 feet apart, 18 inches apart in the rows. The ground should be well worked to produce good heads. and hoed frequently during the season. If the Cabbage worm or otler insect pests prove troublesome, Hammond's Slug-Shot is safe, easily applied. and effectual. One ounce of seed will produce about 2.500 plants; four ounces to the acre.

All-Hearl Early. A second-early sort; lieads large, round, flat, very solid, and uniform in size; good keeper. Pkt. 10c., oz. 60c., 1/4 lb. $\$ 2.00$.

Early Durarf Flat Dutch. Heads large, solid, crisp, and tender. Pkt. 10c., oz. 65e., 1/4 lb. $\$ 2.25$.

Early Jersey Wakefield. The best first-early pointed-head Cabbage. Of uniform size, solid, and of fine quality. Plkt. 10c., oz. 70 cts.. $1 / 4 \mathrm{lb}$. $\$ 2.25$.

Mammolh Rock Red. Produces large, red, solid heads. Pkt. 10c., oz. $75 \mathrm{c}$. 1/4 lb. $\$ 2.75$.

Premium Late Flat Dutch. Heads are solid. perfect in shape, and attain large size. One of the best late varieties. Pkt. 10c., oz. 90c., 1/4 lb. $\$ 3.25$.

Saroy, Perfection Drumhead. The best Savoy Cabbage for market gardeners, producing large lieads that have the rich flavor of Canliflower. Pkt. 10c., oz. 70c.. 1/4 lb. $\$ 2.50$.

Charleston Wakefichl. Is larger. but fully equal in quality to any of its class. Plit. 10c., oz. 60c., $1 / 4$ lb. $\$ 2.00$

Copenhagen Market. Very early. round head; slort stemmed. P'kt. 10c., oz. \$1.35, 1/4 lb. \$4.25.

Danish Ballhead Lale. Very ronnd; solid winter sort. A fine shipper. Pkt. 10c., oz. \$1.25, 1/4 lb. $\$ 4.00$.

\section{Carrot}

Culture.-Will grow to greatest perfection in warm, deep, rather light and fairly fertile soil. For early crop, sow in May and Jume in drills about 1 foot apart. thinning out to 4 inches in the row ; sow for main crop in . Tune and July. One ounce will sow 100 feet of drill; three to four pounds for one acre.

Danvers Half-Long. A rich orange-red variety. very smooth and handsome producing large crops. Flesh sweet. crisp and trinder. Plkt. 10c.. oz. 25 c.. $1 / 4$ Ib. $75 c$

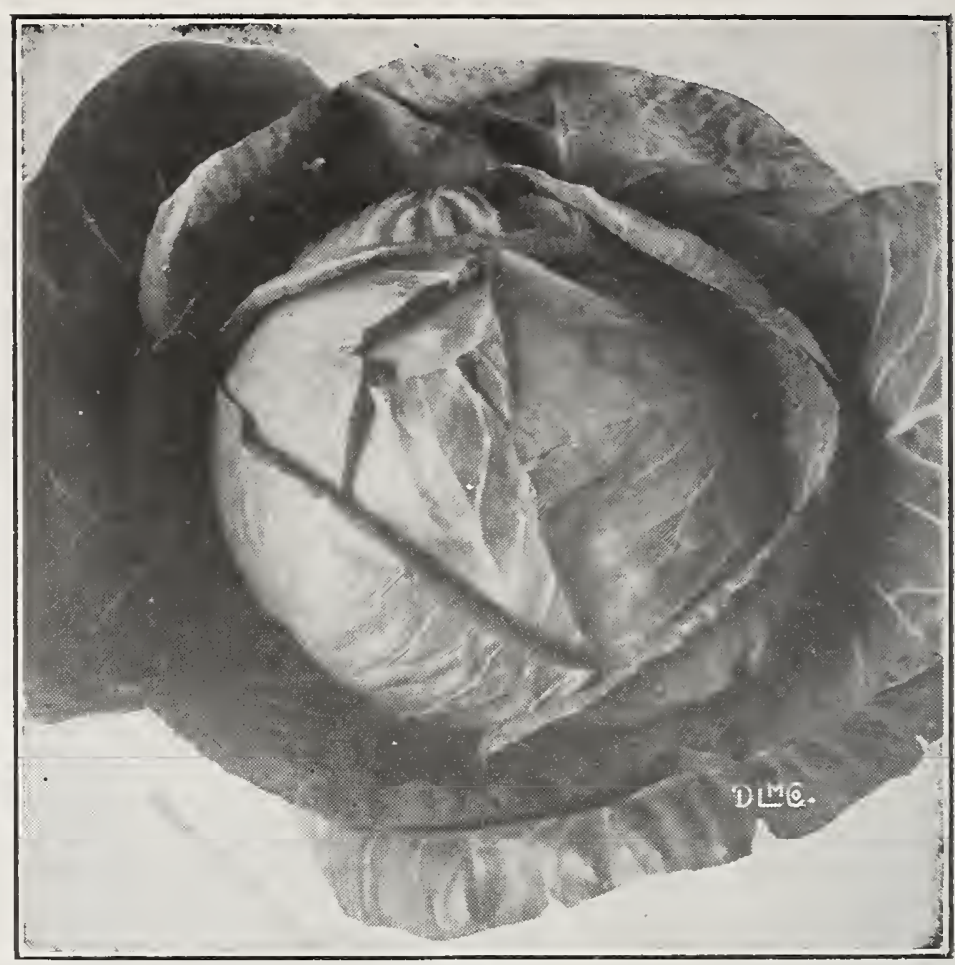

Copenhagen Market Cabbage

\section{CARROT-Continued}

Improved Long Orange. When small. is an excellent variety for the table; full-grown. is a leading sort for stock feeding. Pkt. 10c., oz. $25 \mathrm{c} ., 1 / 4 \mathrm{lb} .75 \mathrm{c}$.

Scarlet Horn. Excellent for early planting out-ofdoors. Tops are small. Roots are top-shaped, tapering abruptly to a small top-skin orangered. Pkt. 10c.. 0z. 25c., 1/4 lb. 75c.

Oxheart. Very thick and short, very sweet. Plit. 10c., oz. 25c., 1/4 lb. $75 \mathrm{c}$.

Chantenay Half-Long. Style of Nantes. broader shoulder. Plkt. 10c, oz. 25c, 1/4 1b. $75 \mathrm{c}$.

Large White Belgium. Very large; for stock. Pkt. 10c., oz. 20c., $1 / 4$ lb. 60e.

\section{Celery}

Culture.-During April or May, sow seed $1 / 4$ inch deep, in drills, either in the open ground or coldframe, keeping the soil well moistened until seed germinates. When the plants are about? inches high, thinning out is necessary, and then, after attaining a height of 5 inches, they are ready to be transplanted, usually in July, to final beds of very rich soil. Set plants every 6 inclies in rows 3 feet apart. For early use, begin blanching in September by drawing up the soil to within a few inches of the top and firm well around the plants. One ounce will produce about 5.000 plants.

Dwarf Golden Hearl. Large lieart: solid, round stalks. blanching golden yellow; (crisp and fine; of excellent flavor: a good keeper. Pkt. 10c. oz. 50c., $1 / 4$ lb. $\$ 1.75$.

Giant Pascal. Very large, thick. solid and crisp, with a rich, nutty fiaror. A good-keeping green Celery. Pkt. 10c., oz. 55c., 1/a lb. \$1.85.

Golden Self-blanching. Stalks and heart a rich golden vellow; plants dwarf and stocky. Pkt. $10 c .$, oz. $\$ 1.65,1 / 4$ lb. $\$ 6.00$.

Silver Self-IBlanching. A sport from the Golden Self-Blanching. of lobust habit and having the perfect whiteness of the White Plume. Pkt. $10 c .$. oz. $\$ 1.55$. $1 / 4 \quad$ lb. $\$ 5.60$.

While Plume. A very popular market variety. In large plants the stalks, hearts and inner leaves become white without any blanching. Plit. 10c., 0z. 75c.. 1/4 lb. $\$ 2.00$.

Winler Queen. A rery thick, solid stalk with a great deal of heart ; excellent quality and a good keejer. Pkt. $10 c_{.} .0 z .90 c . .1 / 4$ lb. $\$ 3.00$. 


\section{Chervil}

Culture.-Cultivate and use the curled variety of Chervil like parsley. Highly esteemed for garnishing and for flavoring soups and salads. Sow at any time in the spring in shallow drills, 1 foot apart, in well-prepared ground.

Curled. Leaves densely curled and far superior to parsley in flavor. Ready for use in about ten weeks from sowing the seed. Pkt. 10c., oz. 25c., $1 / 4$ lb. $75 \mathrm{c}$.

\section{Corn, Sweet or Sugar}

Culture.-Wait until the ground has become warm before planting, as cold, wet soil will rot the seed. For a succession, plant every two weeks until the middle of July in rich, well-manured soil, in hills 3 feet apart each way, covering about $1 / 2$ inch; thin out to three plants to a hill. One quart will plant 200 hills; eight to ten quarts to an acree, in hills.

Country Gentleman. Very sweet; large ears. One of the best for main crop. Pkt. 15c., pt. 40c., qt. $70 \mathrm{c} ., 4$ qts. $\$ 2.60$.

Early Champion. Second-early sort. Twelverowed white ears of good size. Of fine quality and a good seller. Pkt. $15 \mathrm{c}$, pt. $35 \mathrm{c}$. , qt. $60 \mathrm{c}$, 4 qts. $\$ 2.25$.

Early Minnesola. One of the earliest varieties grown. Dwarf; ears small. Pkt. 15c., pt. 35c., qt. $60 \mathrm{c} ., 4$ qts. $\$ 2.25$

White Cob Cory. Ears double the size of the old Cory. Pkt. 15c., pt. 35c., qt. 60c., 4 qts. $\$ 2.25$.

Croslyy's Early. Medium size, very sweet thick graius second early or main crop. Pkt. 15c., pt. $35 \mathrm{c} .$, qt. $60 \mathrm{c}, 4$ qts. $\$ 2.25$.

Early Evergreen. About ten days earlier than Stowell's Evergreen. Kernels white; quality of the best. Pkt. $15 \mathrm{c}$, pt. $35 \mathrm{c} .$, qt. 60c., 4 qts. $\$ 2.25$.

Golden Bantam. The earliest and the finest Sweet Corn for the home garden. Produces two or three small. creamy yellow ears to the stalk. Kernels full and sweet. Plkt. 15c., pt. 40c., at. 70 c., 4 qts. $\$ 2.60$.

Metropolitan. A medium-early variety with sturdy stalks and ten- to twelve-rowed ears about ? inches long; kernels large and of excellent quality. Pkt. 15c., pt. 40c., qt. 70c., 4 qts. $\$ 2.60$.

Stowell's Evergreen. The standard main-crop valiety for the home garden. Fars are large, very white, with deep-set grains of finest quality. Pkt. 15c., pt. 40c., qt. 70c., 4 qts. $\$ 2.60$.

\section{Pop Corn}

While Rice. Ears 5 to 7 inches long, with long, pointed keruels resembling rice. A heavy vielder, maturing late. Fine for popping. Pt. 25c. qt. $40 \mathrm{c}$.

\section{Corn Salad, or Fetticus}

Highly appreciated and much grown where lettuce and other salads do not succeed. Prepared in the same manner as lettuce, and makes an exrellent dish. Sow the seed thickly in shallow drills in September, and firm the soil well over it if the weather be dry. An ounce of seed will sow a bed 20 feet square. Pkt. 10c., oz. 25c., 1/4 lb. s.sc., lb. $\$ 2.60$.

\section{Cucumber}

Culture-Warm, settled weather, with light mellow ground, are important factors in success ful Cucumber growing. Plant the seed in wellenriched hills about 4 feet apart each way, and, as soon as danger from insects is over, thin the plants to leave four of the strongest in each hill. For succession, sow at intervals of every two weeks until midsummer. Extra-early crops are obtained by planting the seed in hotbeds in April, upon pieces of sod turned upside down, and removing them to hills in the open ground as soon as the weather is warm enough. The vines bear longer if the fruits are gathered as soon as large enough. An ounce of seed will plant 100 hills; two pounds will plant an acre.

Early Frame. Excellent for both table and pickling. Fruit straight, bright green; flesh tender and crisp. Plst. 10c., oz. 20c, 1/4 lb. 60c.

Fordhook. Fruits long, smooth, and dark green; very productive. Pkt. $10 \mathrm{c}$, oz. $25 \mathrm{c} ., 1 / 4 \mathrm{lb} .75 \mathrm{c}$.

White Spine Improved. Early, prolific. Fruit medium size, good shape, light green, with a few white spines on the surface. Pkt. 10c., oz. 20c., $1 / 4$ lb. (i5c.

West India Gherkin. Small, rough, prickly fruits used for pickling. Plit. 10c., oz. 30c., 1/4 lb. 80c.

Improved Telegraph. The English forcing Cucumber. Pkt. 30c.

Long Green. Long and crisp; a popular rariety for pickles. Pkt, 10c., oz. 20c., $1 / 4$ lb. 60c.

\section{Egg Plant}

Cuiture.-Sow seed in hotbeds in early March, transplant to small pots. and plunge them in the same beds; this to make them strong and stocky. Plant out in May or June after weather has become settled. Set the plants in rows 3 feet apart each way, and give them a thorough cultivation. An ounce of seed will produce 1.000 plants.

Black Beauty. Fruit broad and thick, lustrous purplish black; very productive; of excellent quality. Pkt. 15c., oz. S5c., 1/4 lb. $\$ 3.00$.

New York Improved Spineless. Fruits deep purple, large, smooth, free from spines; flesh white, tender, and of delicate flavor. Pkt. $15 \mathrm{c} ., \mathrm{oz}$ S.jc., $1 / 4 \cdot 1 \mathrm{lb} . \$ 3.00$.

Early Long Purple. Fruit longer and smaller than the above sort; hardy; productive. Plit. 15c., oz. S5c., 1/4 lb. $\$ 3.00$.

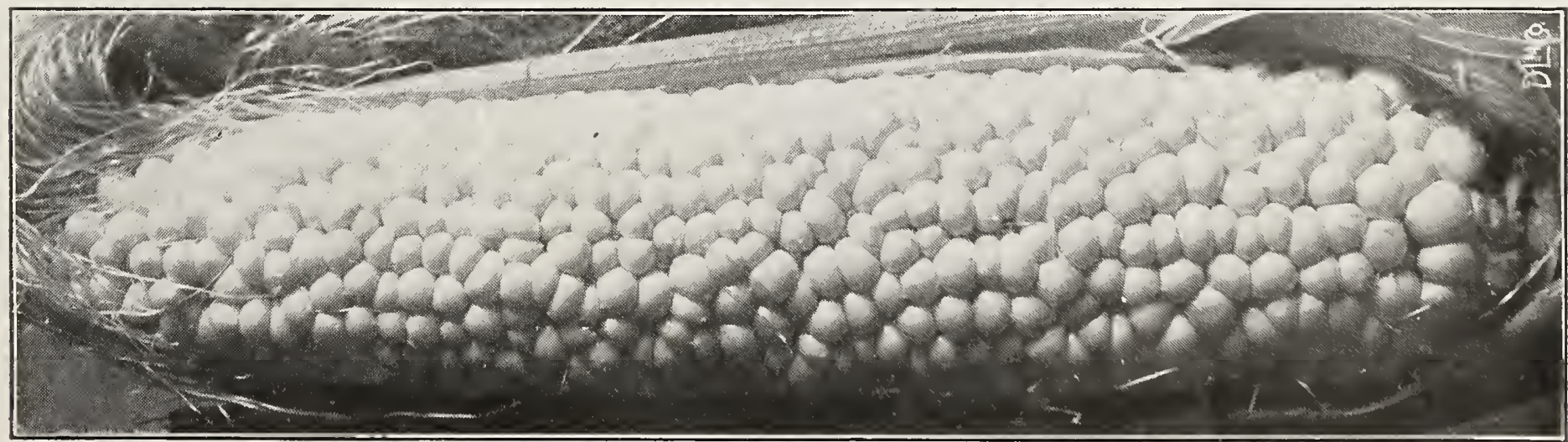




\section{Endive}

Caltuse.-For early crop, sow seed in April in drills 15 inches apart, and thin the seedlings to stand 12 inches apart in the rows. Sowings for the main crop may be made in June or July, as the vegetable is used principally in fall or winter. The inner leaves may be blanched by tring the tips of the outer ones together. or by laying boards over the plants. An ounce of seed will sow 150 feet of drill.

Batavian. Leaves broad, twisted or waved, with thick white midrib. Makes a fine "head" and blanches easily. The most extensively grown variety. Pkt. 10c., oz. 35c., 1/4 lb. 90c., lb. $\$ 3.00$. Green Curled. A hardy variety with beautifully curled dark green leaves which are very crisp and tender when blanched. Pkt. 10c., oz. 30c., $1 / 4$ lb. $85 \mathrm{c} ., \mathrm{lb} . \$ 3.00$.

\section{Kale}

Culture.-Sow about the middle of April, in prepared beds. covering thinly and evenly; plant out in June, following the directions recommended for cabbage.

Drarf Green Scotch Curled. The leaves are very curly, bright green, tender, and of delicate flavor. Pkt. 10c., oz. 30c., 1/4 lb. S5c., lb. $\$ 3.25$.

\section{Kohl-Rabi}

Cultare.-If weather is favorable, sow seed in April in rows 18 inches apart, thinning the seedlings to stand 6 to $S$ inches apart. 'They are fit for use when 3 to 4 inches in diameter. For late crops, sow seed in June or July. An ounce of seed will produce 2.500 plants.

Early Purple Vienna. Very early, with small top. leaf-stems tinged with purple. Bulbs of medium size, purple; flesh white and delicate. Good for forcing and early outdoor planting. Pkt. 10c., oz. 35c., $1 / 4$ lb. $\$ 1.10$.

Early White Vienna. A rapid-growing sort with small foliage: matures the fine, round, white bulbs quite early. Pkt. 10c., oz. 35c., 1/4 lb. $\$ 1.10$.

\section{Lettuce}

Culture.-For very early outdoor crop, sow seed in hotbeds in February, transplanting the seedlings to the garden in April. S to 12 inclies apart. in rows 12 inches apart. For a succession until frost, sow in drills in the open ground at intervals of every two or three weeks, thinning the plants to stand 6 to $S$ inches apart. Half an ounce of seed will sow 100 feet of drill and produce about 1,500 plants. When wanted as cut salad, sow the seed thickly in rows or broadcast.

Big Boston. Large, solid, crisp, compact lieads that find a ready sale wherever offered. Fine variety for the lome garden also. Pkt. 10c., oz. $25 \mathrm{c} ., 1 / 4 \mathrm{lb}$. SOc.

Early Curled Simpson. A loose-leaf variety that is ready for use very early. Tender and of a delicate flavor. One of the best for market; excellent for forcing. Pkt. 10c., oz. 25c., 1/4 lb. $80 c$.

Hanson. Forms large. solid heads. somewlat crumpled at all seasons. Splendid for home gardens. Pkt. 10c., oz. 20c., 1/4 lb. 65c.

May King. Heads of good size, light green in color, the inner leaves blanching to a rich golden yellow; crisp and tender. Plit. 10c., oz. 25c., $1 / 4 \mathrm{lb} .75 \mathrm{c}$

Tennisball. Forms a handsome compact head with very few outside leaves; crisp and tender. Pkt. $10 \mathrm{c} ., 0 \% .25 \mathrm{c}$. . 1/4. $1 \mathrm{~b} .75 \mathrm{c}$.

White Paris Cos. A variety with long, narrow. upright leaves; does not lead, but when tied up blanches very nicely. One of the finest varieties of Cos Lettuce for summer use, rapidly becoming popular with growers. P'kt. 10c., oz. $25 \mathrm{c}$, I/4 $3 \mathrm{~b} .80 \mathrm{c}$.
LETTUCE--Continued

Salamanda. Large heads that stand the heat and drought. Pkt. 10c., oz. 25 c., 1/4 lb. $75 \mathrm{c}$

Black Seed Simpson. Nearly double the size of Curled Simpson. Pkt. 10c.. oz. 20c., 1/4 lb. 65c.

\section{Leek}

Culture.-Sow seed in hotbed in early spring, later transplanting seedlings to the open ground, 8 inches apart, in rows from 12 to 15 inches apart. For a winter supply, sow seed in the open ground in early spring and thin the seedlings until they have room for development, or transplant them as above. Store like celery for winter. An ounce of seed will sow about 100 feet of drill.

American Flag. A strong-growing early variety of mild flavor. Large, thick stems. Pkt. 10c., oz. 40c., $1 / 4$ lb. $\$ 1.35$.

\section{Muskmelon}

Culture.-In May, plant in hills 5 to 6 feet apart each way, in soil that is light and moderately rich-ten seeds to each hill. When the plants are well up, thin out to three. Pinch the ends of the growing shoots to induce early fruiting. One ounce of seed will sow fifty hills.

Emerald Gem. Early ; flesh thick and salmoncolored; granular. sweet, and delicious. An old favorite. Pkt. $10 \mathrm{c} ., 0 \mathrm{z}, 20 \mathrm{c} ., 1 / 4 \mathrm{lb} .60 \mathrm{c}$.

Paul Rose. Medium-sized; flesh salmon-colored. thick and solid. Splendid shipper and good keeper. Pkt. 10c., oz. 20c., $1 / 4$ lb. 60c.

Rocky Ford. Oval-shaped, small, and uniform; thick-meated; flesh light green in color, of fine. luscious flavor. Pkt. 10c.. oz. $25 \mathrm{c} ., 1 / 4 \mathrm{lb}$. $75 \mathrm{c}$.

Extra Early Hackiensack. Large, round and of good quality. Pkt. 10c., oz. 25c., 1/4 lb. $75 \mathrm{c}$.

\section{Watermelon}

Culture.-Hills should be 6 to $S$ feet apart each way. Plant in May, ten seeds to a hill, and when plants are well up, thin out to three. Pinch the ends of the growing shoots to induce early fruiting. A light, rich soil is preferred.

Cole's Early. The beautiful, bright red flesh is crisp and of delicate texture-granulated. cool. and sparkling. Lusciously sweet and refreshing. Splendid small melon. Pkt. 10c., oz. 20c.

Mountain Srreet. A late variety with dark green skin and red flesh that is both firm and sweet; long, tapering to stem end. Pkt. 10c. oz. 20c.

\section{Mustard}

Culture.-For early use, sow in hotbeds in March; for general use. sow as early in spring as ground can be worked, in drills about 18 inches apart, covering seed firmly with about $1 / 2$ inch of fine soil. For succession, continue sowings every two or three weeks. Keep free of weeds; water freely. One ounce will sow 75 feet of row. Giant Southern Curled. Leaves large, light green. with a vellow tinge, much crimped at the edges. Will stand a long time before running to seed. Plt. 10c., oz. 15c., 1/4 lb. 50c.

\section{Onion}

Culture.-Sow in rich, sandy soil, in drills 1 foot apart. as soon as the ground can be worked in spring. at the rate of five to six pounds to the acre. Thin to 3 or 4 inches, and keep weeds under control.

Large Red Welhersfield. Grows to full size the first season from seed. Onions are large, flat, with skin of purplish red color and flesh purplish white. An excellent keeper. Pkt. 10c., oz. $40 \mathrm{c} ., 1 / 4$ lb. $\$ 1.25$. 


\section{ONION--Continued}

Prizetaker. A very large late or main-crop Onion, nearly globular in form; skin yellowish brown; flesh creamy white, very mild, tender, and of fine flavor. Pkt. 10c., oz. 50c., 1/4 lb. $\$ 1.50$.

Southport Red Globe. Large, perfect. globe-shaped bulbs of deep purplish red color. Flesh is white tinged with light purple, fairly mild, fine-grained and tender. Pkt. 10c., oz. 35c., 1/4 lb. $\$ 1.15$.

Southport Yellow Globe. Rich yellow color ; ripens down evenly and keeps well; flesh creamy white, fine-grained, and of excellent flavor. Very hardy and extremely productive. Pkt. 10c., oz. $40 \mathrm{c} ., 1 / 4 \mathrm{lb}$. $\$ 1.25$.

Southport White Globe. Large, handsome, pure white. globe-shaped bulbs, which are full at the shoulder and base. Very productive and a good keeper. Pkt. 10c., oz. 50c.. 1/4 lb. $\$ 1.50$.

Ailsa Craig. The skin is a pale straw color and oval in shape. Pkt. 10c.. oz. $\$ 1.25,1 / 4$ lb. $\$ 4.50$.

White Bermula. Flat; grows very quickly, exceedingly mild in flavor. Pkt, 10c., oz. 40c., 1/4 lb. $\$ 1.25$

Yellow Globe Danvers. The standard variety for main crop. Bulbs are a rich copper-yellow color flesh creamy white, crisp, solid, mild, and of good flavor. Pkt. 10c., oz. 40c.. 1/4 lb. $\$ 1.25$.

white Portugal. Fine white sort for sets or for use when young: mature bulbs of medium size, flattened globe shape, of mild flavor and beauti ful silver-white skin. Matures about ten days earlier than Southport White Globe. Pkt. 10e., oz. 50c., 1/4 lb. $\$ 1.50$.

\section{Onion Sets}

Culture.-By planting sets. Onions may be had much earlier than from spring-sown seed. To obtain large Onions, sets should be planted 3 to 4 inches apart, in rows 1 foot apart, as soon as frost is out of the ground.

$\left.\begin{array}{l}\text { Red Sets. } \\ \text { White Sets. }\end{array}\right\}$ Write for prices.

Yellow Sets.

\section{Okra}

Culture-Casy to grow in any good soil. Sow the seed thickly in rich ground about the middle of May, or when the ground has become warm, in drills 3 feet apart, 1 inch deep; thin to 10 inches apart in drills. One ounce will plant 100 hills. Long Green. Tall growing, very productive of long green pods of good quality. The pods of Okra are used in soups, stews, ete, to which they impart a rich flavor. Pkt. 10c., oz. 15c., $1 / 4 \mathrm{lb} .30 \mathrm{c}$.

White Velvet. Long, tender, white pods; smooth and velvety in appearance. Pkt. 10c., oz. 15c. $1 / 4$ lb. $50 \mathrm{c}$.

\section{Parsley}

Culture-As the seed is slow in germinating, it should be sown as early in spring as possible in drills 1 foot apart and $1 / 2$ inch deep. When the plants are well advanced, thin out to 6 inches apart in the row. By making a second sowing under glass in July or August, a supply can be had throughout the winter. One ounce will sow 100 feet of drill.

Fine Double Curled. Handsome, dark green, deeply curled leaves that are unequaled for flavoring or garnishing. Pkt. 10c., oz. 20c., 1/4 lb. 65c.

Moss Curled. A variety somewhat resembling the above in appearance, but of more rapid growth. Pkt. 10c., oz. 15c., 1/4 lb. 50c.

\section{Parsnip}

Culture.-Sow the seed in deep, rich, mellow soil in drills $11 / 2$ feet apart and $1 \%$ inch deep as soon as the ground can be worked in spring. Thin plants to 6 inches apart in the rows and cultivate frequently. Flavor is improved by a hard frost. One ounce will sow 200 feet of drill.
PARSNIP-Continued

Guernsey. Roots half-long, white, very smooth and fine-grained. Heavy cropper ; superior quality I'kt. $10 \mathrm{c}, 0 \mathrm{z}, 25 \mathrm{c}, 1 / 4 \mathrm{lb}, 75 \mathrm{c}, \mathrm{lb}, \$ 2.25$.

Hollow Crown. Medium length roots, very smooth and of the finest quality. Very fine table sort. Pkt. 10c., oz. 25c., 1/4 lb. $75 \mathrm{c} .$, lb. $\$ 2.25$.

\section{Peas}

Culture.-For market, sow in single rows 1 inch apart and 2 to 3 inches deep, rows from 2 to 4 feet apart. In garden, sow in double rows 6 to 8 inches apart. Begin sowing extra-early varieties as soon as the ground can be worked in March; for a succession, every two weeks until June. One quart to 100 feet of drill. One and one-half to two bushels to the acre.

\section{Extra Early Peas}

First of Al!. An extremely early variety of vigorous growth, usually attaining a height of $21 \%$ feet and bearing small-podded Peas of fair quality. Height. $21 \%$ feet. Pkt. 15c., pt. 45c., qt. $90 \mathrm{c}, 4$ qts. $\$ 3.25$.

Gradus, or Prosperity. One of the most popular of the wrinkled sorts. Pods are long, containing very large Peas that are unexcelled for sweetness. Height, 3 feet. Pkt. $15 \mathrm{c}$, pt. $50 \mathrm{c}$, qt. $\$ 1.00,4$ gts. $\$ 3.50$.

Laxtonian. Iuch like Gradus in shape and size of pod, is equally sweet. and matures somewhat earlier. Height $11 / 2$ feet. Pkt. 15c., pt. 60c., qt. $\$ 1.20,+$ qts. $\$ 4.50$.

Nott's Excelsior. Very productive of pods 3 inches long which contain six or seven large, sweet Peas of the finest quality Height, 1 foot Pkt. $15 \mathrm{c.}$, pt. 50 c., qt. $\$ 1.00 \%$ q qts. $\$ 3.50$.

Sulton's Excelsior. An extra early dwarf wrinkled Pea. P'kt. 15c., pt. 60c., qt. $\$ 1.20$, 4 qts. $\$ 4.50$.

American ironder. Height, 10 to 12 inches. Extra early ; of dwarf, compact growth, wrinkled, of the finest quality. Pkt. 15c., pt. 45c., qt. S0c., 4 nts. $\$ 300$.

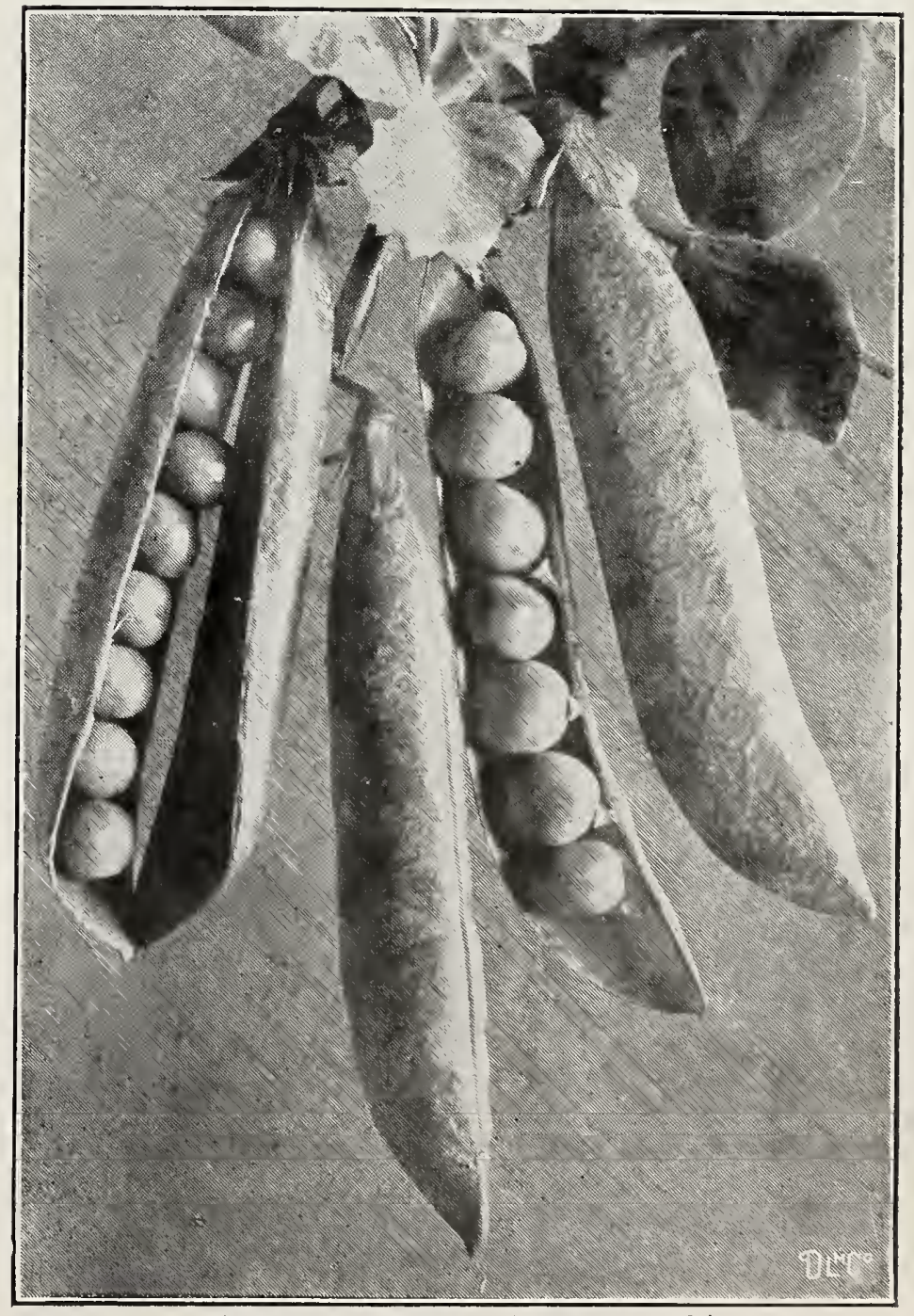

Telephone Peas. (See 4 page 10.) 


\section{Medium Early Peas}

Champion of England. An old standard that is enormously productive. and the Peas are of delicious flavor. Fine for the home garden. Height, 5 feet. Plit. 15 c.. pt. 50c., qt. $\$ 1.00 .4$ qts. $\$ 3.75$.

Daisy, or Dwarf Telephone. Remarkably productive of long pods that are well filled with the deliciously sweet Peas. Height, 11ㅡㄹ feet. Pkt. $15 \mathrm{c}$. pt. $45 \mathrm{c}$. qt. $90 \mathrm{c} ., 4$ qts. $\$ 3.25$.

Dulie of Albany. A very superior Pea of quick growth; pods dark green. well filled. Height, 5 feet. Pkt. $15 \mathrm{c}$. pt. 50c.. qt. $\$ 1.00 .4$ qts. $\$ 3.50$.

IIorsford's Marliet-Garden. Noted for its productiveness. Medium-sized pods that are well filled with Peas of fine flavor. Height, $21 / 2$ feet. Plkt. $15 \mathrm{c} ., \mathrm{pt}$. 45c., qt. $80 \mathrm{c}$. 4 qts. $\$ 3.00$.

IcLean's Adrancer. Ripens immediately after the extra-early sorts and is greatly productive of handsome pods containing I'cas of delicious flavol. Height, 21\% feet. Plit. 15c., pt. 45̃c., qt. 90c., 4 ats. $\$ 3.25$.

\section{Late, or Main Crop Peas}

Alderman. The largest-podded of all Peas. even larger than the Duke of Albany, and also much darker in color. Vines are robust and decidedly heavy yielders. Height, 5 feet. Pkt. $15 \mathrm{c} .$, pt. 50c., qt. $\$ 1.00 .4$ qts. $\$ 3.50$.

Telephone. Pods 4 to $4 \frac{1}{2}$ inches long. light green in color, and filled with large. sweet, tender Peas. Height, 5 feet. Pkt. $15 \mathrm{c}$, pt. $45 \mathrm{c}$, qt. Soc., 4 qts. $\$ 3.00$.

\section{Pepper}

Culture.-Sow in hotbeds in March or April. or in a warm. sheltered border in May, and, when the season is favorable, transplant in rows 2 feet apart and 18 inches apart in the row, in good, rich ground. One ounce will produce about 1.000 plants. Bell, or IRull Nose. A large, inverted, bell-shaped Pepper. valued for pickling or for filling. Thick, hard flesh. not very pungent, and remarkably early for such a large fruit. Pkt. 10c., oz. 90c., $1 / 4$ ib. $\$ 2.90$.

Long Red Cayenne. Fruit 3 to 4 inches long, conical in form. of a bright red color, and very productive. Pkt. 10c., oz. S5c., 1/4 lb. $\$ 3.00$.

Ruby King. Large, scarlet fruits. sweet. and of mild flavor. Vigorous-growing plants. producing from eight to sixteen handsome fruits. Pkt. 10c., oz. $75 \mathrm{c}, 1 / 4$ lb. $\$ 2.50$.

Sweet Mountain. Fxtra-large fruit; very prolific bright, smooth, and handsome; flesh very thick, mild. and sweet-flavored. Rich red when mature. Pkt. 10c., oz. 90c., 1/4 lb. $\$ 2.90$.

\section{Potatoes}

Culture.-Plant as early in spring as the ground can be had in fair working order, in hills or ridges about 3 feet apart, covering in light. warm soils about 4 inches deep. but in cold. wet situations. $21 \%$ or 3 inches will be sufficient. One peck will plant about 125 hills; twelve to fourteen bushels to the acre.

Orders will be taken subject to market prices

Beauly of IIelyon. Skin flesh-colored; flesh pure white; early ; very productive: of finsst quality.

Carman No. 1. An enormons yielder: handsome and uniformly large.

Early Rose. Popular market sort; very early ; fine quality; very productive.

Green Mountain. White skin and flesh; excellent quality; a heary rielder.

Irish Cobbler. Very large and white; heary cropper; extra early ; of fine quality.

\section{Pumpkin}

Culture-May be planted about the middle of spring among the Indian corn or in the field or garden, in hills 8 to 10 feet apart each way, four seeds in a hill. In other respects is cultivated in same manner as melons and cucumbers. Avoid planting near other vines. One ounce will produce fifty hills; three to four pounds to one acre. Commecticut Yellow Field. The variety most generally planted for stock feeding. Is generally planted with corn. Plit. 10c., oz. 15c., 1/4 lb. 50c. Large Cheese. Flat and round like a cheese; color of skin deep orange, flesh somewhat lighter. One of the best for table use. Plit. $10 \mathrm{c}, 0 \mathrm{z}, 20 \mathrm{c}$. $1 / 4 \mathrm{lb} .65 \mathrm{c}$.

Iammolh King. Truly a giant among Pumpkins. In shape it is round, flat. and slightly ribbed; color of skin and flesh bright golden yellow and of good quality. Pkt. 10c., oz. 25c., 1/4 lb. S0c.

Winter Luxury. A fine keeper and one of the best for pies. Pkt, 10c., oz. 25c., 1/4 lb. 75c.

\section{Radish}

Culture.-The soil for Radishes should be rery rich. light and mellow, well broken by digging, as their tender and mild qualities depend much upon their rapid growth. For very early use, sow in gentle hotbeds in February, and in the open air as soon as the ground can be worked. at intervals of ten or twelve days for a succession as long as they may be wanted. The winter varieties should be sown in August. lifted before severe frost, and stored in the cellar. One ounce will sow 100 feet of drill.

Improved French Brealifast. An olive-shaped medium-sized variety that is red above and white below: crisp. sweet and tender. Pkt. 10c., oz. $20 \mathrm{c} . .1 / 4 \mathrm{lb} .60 \mathrm{c}$

Improved White Icicle. One of the finest long white forcing Radishes known; flavor exceedingly fine. Pkt. 10c., oz. 20c., 1/4 lb. 60c.

Red Globe Forcing. Fine for forcing or open ground. Tender and crisp. Pkt. $10 \mathrm{c}$. oz. 20c. $1 / 4$ lb. $60 \mathrm{c}$.

White Tip. A handsome and popnlar sort that is crisn and of fine flavor. Plit. 10c., oz. 20c., 1/4 lb. $60 \mathrm{c}$.

Rose China Winter Radish. 4 to 5 inches long by 2 inches in diameter; skin rosy-red; good keeper. Pkt. 10c., oz. 25c., 1/4 lb. 75c.

\section{Spinach}

Culture.-For early use, sow very early in spring, and for succession at intervals. The main crop. for spring and winter use. should be sown in September and the plants covered for winter. An ounce of seed will sow 50 feet of drill; twenty pounds to the acre.

Bloomsdale Savoy. Hardy and well adapted for winter crons. ILeaves large and wrinkled. Pkt. $10 c .$. oz. $15 \mathrm{c} ., 1 / 4$ lb. $40 \mathrm{c} . .1 \mathrm{lb} . \$ 1.10$.

Long-Standing. Dark green leaves; stands the longest before running to seed. Pkt. 10c., oz. $15 \mathrm{c} .1 / 4 \mathrm{lb}$. $45 \mathrm{c} ., 1 \mathrm{~b} . \$ 1.50$.

New Zealand. A distinct variety, growing well during hot weather. Pkt. 10c., oz. $25 \mathrm{c}$, $1 / 4 \mathrm{lb}$. 75 c.. Ib. $\$ 2.50$.

Victoria. Fine for spring sowing; a little later than Long-Standing. Color dark green. Pkt. 10c., oz. 15c., $1 / 4$ lb. 45c., lb. $\$ 1.50$.

\section{Salsify, or Oyster Plant}

Culture.-Sow seed in light, deep soil early in spring. in drills 12 inches apart and 1 inch deep, thinning out the young plants to 4 or 5 inches.

Nammoth Sandwich Island. Roots two or three times the size of ordinary Salsify, and of more agreeable flavor. Pure white. Pkt. 10c., oz. $30 c ., 1 / 4$ lb. $\$ 1.00$ 


\section{Tomato}

Culture.-Sow in hotbeds from six to eight weeks before they can be set out-of-doors; when the plants have four leaves, transplant into shallow boxes or coldframes, setting them 4 to 5 inches apart. Set out-of-doors as soon as danger from frost is over.

Acme. Early ; medium-sized ; smooth, solid, purplish pink; prolific. Pkt. 10c., 1/2 oz. 25c., oz. 50 c., $1 / 4$ lb. $\$ 1.50$.

Crimson Cushion. Crimson-scarlet, solid, meaty fruits. Pkt. 10c., 1/2 oz. 30c., oz. 60c., 1/4 lb. $\$ 1.80$.

Dwarf Stone. Very solid fruits of fine flavor. Pkt. 10c., 1/2 oz. 25c., oz. 50c., 1/1/ lb. $\$ 1.50$.

Earliana. A very early, prolific Tomato; fruits large, smooth, red. Pkt. 10c., 1/2 oz. 25c., oz. 50 c.. $1 / 4$ lb. $\$ 1.50$.

New Stone. Large, bright red. solid, and astonishingly heavy. Pkt. 10c., 1/2 oz. 25c., oz. 50c., 1/4 lb. $\$ 1.50$.

Ponderosa. Bright red; few-seeded; fruits enormous. Pkt. 10c., 1/2 oz. 40c., oz. 70c., 1/1 lb. $\$ 2.10$.

Yellow Plum. Fruit plum-shaped; flesh yellow and good. Pkt. 10c., 1/2 oz. 30c., oz. 55c., 1/4 lb. $\$ 1.75$.

John PBaer. Brilliant red variety ; perfect, solid, high crown fruit. Pkt. 10c., $1 / 2$ oz. 40c., oz. $75 c ., 1 / 4 \quad l b . \$ 2.25$.

Bonny Best. An extra early, scarlet, round. The fruit is very even in size and shape. Plkt. 10c., $1 / 2$ oz. $25 c .$, oz. 50 c., $1 / 4$ lb. $\$ 1.60$.

Dwarf Champion. The plant is of dwarf and compact growth. Pkt. 10c., 1/2 oz. 25c., oz. 50c., $1 / 4 \quad$ lb. $\$ 1.60$.

Challi's Early Jewel. About a week later than Earliana. Smooth and solid. Pkt. 10c., 1/2 oz. 25 c., oz. 50 c., $1 / 4$ lb. $\$ 1.60$.

Golden Queen. A good yellow sort; first class quality ; large and solid. Pkt. 10c., $1 / 2$ oz. $25 \mathrm{c.}$ oz. 50 c., $1 / 1 / 4$ lb. $\$ 1.60$.

Red Plum. Bright red, round, regular ; for pickles. Pkt. 10c., $1 / 2$ oz. 30c., oz. 60c., $1 / 4$ ib. $\$ 1.90$.

\section{Squash}

Culture.-About the same as for cucumbers and melons. An ounce of seed will plant twenty to forty hills.

Golden IIubbard. Smaller than the original Hubbard, matures earlier, and is of a rich. orangered color. Pkt. 10c., oz. 30c., 1/4 lb. $\$ 1.00$.

Mammoth Chili. Very large and nutritious: orange colored; keeps well all winter. Fine for stock feeding. Plit. 10c., oz. 30c.. 1/4 lb. $\$ 1.00$.

Giant Summer Crookneck. Yellow fruit; distinct; best for summer. Pkt. 10c., oz. 35c., 1/4 lb. $\$ 1.00$

White Bush. Creamy white, with slightly warted surface. Vines vigorous and productive. Pkt. 10c., oz. 25c., $1 / 4 \mathrm{lb} .75 \mathrm{c}$.

Vegetable Marrow. A favorite English sort: skin greenish yellow; flesh white. Pkt. $10 \mathrm{coz}$. 25c., $1 / 4 \mathrm{lb} .85 \mathrm{c}$ 。

Yellow Bush Scallop. The popular vellow variety. Pkt. 10c., oz. 30c., 1/4 lb. $\$ 1.00$.

\section{Turnip}

Culture.-For early use, sow as soon as luc ground can be worked in spring. in drills 1.5 inches apart, and thin to $S$ inches apart as soon as the plants are large enough.

Improved Golden Ball. One of the sweetest of the yellow-fleshed varieties. Pkt. $10 \mathrm{c.}$, oz. '2) $1 / 4$ lb. $75 \mathrm{c}$.

Purple-Top Strap-Leaf. Flat and medium-sized. purple-red above ground, white below. Flesh white and tender. Pkt. 10c., 0z. 25c., 1/4 lb. $75 \mathrm{c}$.

White Egg. A quick-growing egg-shaped variety with smooth, clear white roots which grow about half out of the ground. Pkt. $10 c .$. nz. $20 \mathrm{c} ., 1 / 4 \mathrm{lb} .65 \mathrm{c}$.

White Globe. Altogether white; globe-shaped. Pkt. 10c.. 0z. 25c., 1/4 lb. $75 \mathrm{c}$.

Early Snowball. Small, and rapid growth; pure white. Pkt. 10c., oz. $25 \mathrm{c}$, 1/4 1b. $75 \mathrm{c} . .1 \mathrm{lb} . \$ 2.00$

Aberkeen. A hardy and productive variety of excellent quality. Pkt. 10c., oz. 25c., 1/1 Jb. 75 c.. lb. $\$ 2.00$.

\section{Rutabaga, or Swedish Turnip}

Improved Yellow Mammoth. Heavy cropper; well flavored. Pkt. 10c., oz. 25c., 1/4 lb. $75 \mathrm{c}$.

Long Island Swede, Flesh rich rellow, of fine quality. Pkt. 10c., oz. 20c., 1/a lb. 60c.. Ib. $\$ 2.00$.

\section{Farm and Field Seeds}

FIELD CORN. Fifty-six pounds to the bushel. Qt. $30 \mathrm{c}$ : peck and bushel prices on application.

Large White Flint. Long slim ears; pure white grain.

Longfellow. A large-eared flint variety, with small cob and deep, yellow kernels.

Improved Golden Beauty. Medium-early Dent Corn, with long ears, small cob, and large grains.

Red-Cob Ensilage. A pure white Dent Corn on a red cob; sweet, tender and juicy.

CowPEAS, Whippoorwill. A first-class green fertilizer; does well on all soils and under adverse conditions. Sow two bushels to the acre.

RYE, Spring. Makes a fine catch-crop.

Giant Winter. Used extensively as a green manure and also for feeding in the green state.

WHEAT, Klondylie. A winter Wheat with white grain; bald. Sixty pounds to the bushel. Plant one and one-half bushels to the acre.

We can take orders at any time at prices ruling at time of shipment

\section{Vegetable Plants}

We grow 500,000 plants of Cabbage, Cauliflower, Eggplant, Lettuce, Kohlrabi, Brussels Sprouts, Peppers, Tomatoes, Celery and Celeriac, and will have them ready to set out as soon as the weather will permit in Spring. These we have in flats, by the hundred; in berry baskets, by the dozen; and in 3- and 4-inch pots. Potted plants are best where only a few are set out. The baskets of a dozen plants are more desirable than those dug out of flats because they are stronger and it is not necessary to disturb the roots until ready to plant. Water the plants rell before cutting each plant out in small squares. Take along as much soil as possible.

Cabbage, Cauliflower, Tomatoes, Peppers, Lettuce, Kohlrabi, Brussels Sprouts, from flats, to $35 \mathrm{cts}$. per doz. Special prices by the 100 or 1000 .

Tomatoes, Eggplants, Peppers, Cabbages and Cauliflower, in baskets of one dozen plants at 3! 50 cents per basket. These plants may be planted out in May, June, and July, are just as good as potted p'1 and will last from one to two weeks in baskets before planting.

Tomatoes, in pots, 50 cts., 75 cts. and $\$ 1.00$ per doz. Special prices by the 100 or 1000 .

Eggplants. 75 cts. to $\$ 1.00$ per doz. Special prices by the 100 or 1000 .

Celery. Extra-strong plants, 75 cts. per 100; extra-strong, transplanted, $\$ 1.50$ per 100 . 


\section{The Hardy Plants of Grandmother's Garden}

Here you will find a list of those hardy plants that made Grandmother's garden the joyous spot it was-plants that repaid loving care with quiet or dashing keauty, with fragrance, with a wealth of bloom from earliest springtime until the frosts of early winter laid them low. Have such a garden of your very own this year. Make your selection generously, for many different kinds and varieties are prophecies of many days of real pleasure as, one after a nother, these old favorites open their blossoms to your wondering eyes. From purest white through all shades of blue, red, yellow; from dainty, fairy-like flowers to massive blooms - the possibilities to the interested gardener are unlimited! We can furnish those listed below in good-sized chumps that, with care, will flower the first season.

ICHILLEA (Yarrow). in variety. Free-blooming hardy perennial with white or red flowers in ilat clusters on long stems. $1-3 \mathrm{ft}$. Jume-Oct.

ICONITUM (Monkshood). Fine for shady places.

Bears showy panicles of helmet-shaped flowers. $4 \mathrm{ft}$. June-Sept.

ALYSSUM saxatile compactum (Gold Dust). Single plants cover a square foot in a year and produce hundreds of yellow flower-heads. 1 it. Apr.--June.

ANEMONE (TVindflower), in variety. Produces (cup-shaped flowers in a variety of striking colors. 1-2 ft. May, June.

IQLLEGIA (Columbine). Fine border plant: blooms early, long and abundantly. 11/2-2 it.

ISTERS. New and especially hardy varieties that will give flowers of unusual size and coloring from midsummer to time for chrysanthemums. $1-21 \% \mathrm{ft}$.

HOLTONIA. Tall and leafy, with aster-like flowers until late in the season. $3 \mathrm{ft}$.

CAMPANULA (Bellflower): A favorite with Grandmother. The profusion of blue and white bell-shaped flowers throughout the summer always attracts attention. 1/2-5 ft.

CANTERBURY BELLS (Campanula Medium). Elegant border or pot plants. Large, bell-sliaped flowers in many shades. $2 \mathrm{ft}$.

CARNATIONS, Iardy Border. Vigorous-growing plants bearing large, double, richly colored flowers. 1-11/2 ft. July-frost.

CHRYSANTHEMUMS. The perennial kinds grow about $21 / 2$ feet high and bloom profusely most of the summer.

CLEMATIS. Hardy climber that is very desirable for covering fences. verandas and embankments. Beautiful when in bloom. $10 \mathrm{ft}$. Midsummer and autumn.

COREOPSIS (Calliopsis). Gives a yellow tone to the garden; flowers fine for cutting. 1 it. Junefrost.

TELPHINIUM (Larkspur). The long spikes of flowers in beautiful tints of blue are strongly effective in beds and borders. 2-3 ft. Midsummer until frost.

DIAN'THUS (Hardy Pinks). Some of our most beautiful and best-loved flowers come nuder this name. Their rich coloring, spicy frasrance and varied form make them very attractive. 1-11\% ft. Bloom till frost

DIELYTRA or DICENTRA spectabilis (BleedingHeart). Popular old-fashioned plant with heartshaped flowers of a beautiful rose-and-wlite combination, borne on long, pendulous stems. $2 \mathrm{ft}$. Spring.

DIGITALIS (Foxglove). Tall spikes of bloom, produced in abundance. Make a brilliant display among shrubbery. 3-5 ft. July, Aug.

DORONICUM. Produces showy, orange-yellow flower's in May, June and July. $2 \mathrm{ft}$

FEVERFEIV (Matricaria). Useful for bedding I for cut flowers; dense clusters of white or ow blooms. To $1 \frac{1}{2} \mathrm{ft}$. All summer.

II (Plantain Lily). The broad. massive age and handsome lily-like flowers make the inkias attractive plants for the border. $2-3 \mathrm{ft}$. LLARDIA (Basket Flower). Slowy plants nat brighten any situation. Thrive anvwhere; require little or no protection. Commence to flower in July and continue until frost. $2 \mathrm{ft}$.
GIPsOPHILA (Baby's Breath). Easily grown plants that produce dainty panicles of bloom; popular for mixing with other cut flowers. $21 / 2$ ft. Summer.

HARDY ORNAIENTAL GRASSES. This class of ornamental plants lend an atmosphere of grace to the beds and borders in summer and furnish spikes or plumes to be used in a dried state for winter decoration.

HELENIUM (Sneezeworth). Strong-growing plants that give an enormous crop of golden yellow flowers in late summer. $3-5 \mathrm{ft}$.

HELIANTIEMUII (Rock or Sun Rose). Freeblooming plants with interesting vellow, or white. sometimes pink and red, flowers that open only in the sun.

HELIANTIUS (Hardy Sunflower). As subjects for the hardy border or for cutting, they are of great value. 3-6 ft. June-Sept.

IELIOPSIS (Orange Sunflower). Bears beautiful golden yellow flowers all summer. $3 \mathrm{ft}$.

HOLLVIOCKS. Make a glorious show in the garden with their splendid spikes of single and double flowers in a wide range of colors.

IYPERICUM (St. John's Wort). An elegant plant, with handsome yellow flowers all summer. $11 / \mathrm{ft}$.

IBERIS ("̂Hardy Candytuft). Evergreen plants that bloom very early, cushioning rock ledges, borders, etc., with banks of bloom.

IRIS, Japanese and others. Wonderful flowers of bold colors, dainty shades-exquisite combinations that make the Irises ever-popular plants for the home garden.

LILIES, Hardy, in variety. Every herbaceous border should have a few Lilies planted here and there. Stately, chaste. some pure white, others charmingly colored, delightfully fragrant. $3-6 \mathrm{ft}$. June-Aug.

LUPINUS (Lupine). The long spikes of peashaped flowers are strikingly liandsome in spring. $3-5 \mathrm{ft}$.

LYCIINS Iaageana hybrida (Japanese Lychnis). Large heads of showy flowers in shades of white, pink. red, yellow and crimson. 11/. ft. June-Sept.

PEONIES, in variety. Greatly improved in recent years; now rival the rose in popularity. Magnificent flowers. Distinctly ornamental, both in foliage and bloom. May, June.

POPPES, in variety. The garden is fairly riotous with color when the Poppies begin to bloom. And the delicate texture of the petals, the size of the flowers, and their graceful poise on long stems make them mighty desirable. 2-4 ft. Early spring.

PHLOX, in variety. A selection of Perennial Phlox that will give brilliantly colored flowers in late summer and fall. $3 \mathrm{ft}$.

PINKS, Hardy Garden. See Dianthus.

PYRE'THRUM. Showy pants with attractive foliage and brilliant and lasting aster-like flowers $2 \mathrm{ft}$.

RUDBECKIA (Coneflower). Compact-growing ; showy, large, yellow flowers witl dark central cones. $2-3 \mathrm{ft}$.

STOKESIA (Coneflower Aster). Bears large attractive flowers, resembling semi-double Asters, all summer. Fine for cut flowers. $2 \mathrm{ft}$.

SWEE'T WILLIAM. Produces large heads of beautifully colored, sweet-scented flowers; easily grown. $11 / 2 \mathrm{ft}$.

TRITOMA (Red-Hot-Poker Plant). Has gorgeous orange-red spikes of bloom; sliould be largely planted. $2-4 \mathrm{ft}$. 


\section{Flower Seeds}

You can have a lot more flowers for the same amount of money if you raise them from seed rather than buy plants. Of course, where it is desired to have flowers ahead of a normal blooming time, plants are preferable; but where one has ample space and the requisite patience, seeds will bring the ultimate joy of richly colored, fragrant blossoms about as surely as will plants. The following list will suggest familiar flowers that you would enjoy growing again, and a venture into planting what may be strangers to you will bring its own reward.

Alyssum, Sweet. Fragrant white flowers in Plkt.

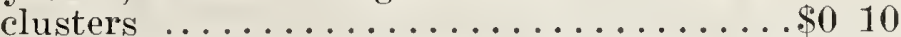

Antirrhinum (Snapdragon). Flowers brightcolored, curiously formed .......10c. and 25

Aquilegia (Columbine). Easily grown from seed; unusual flower's in many rich colors.. 1?

Asters. Wonderful blooms; very slowy..... 10

Bachelor's Butlons. Bright-flowered plants profuse bloomers .................. 10

Balsam. Handsome bushes with rose-like flowers 10 Calendula. Produces its richly colored flowers from early summer to late autumu........ 10

Calliopsis, or Coreopsis. Rich in yellows, reds,

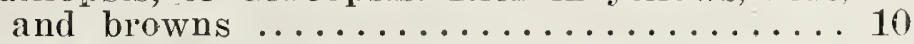

Campanulas. Popular and beautiful plants of

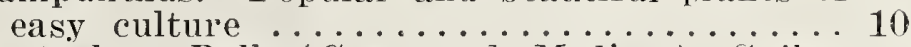

Canterbury Bells (Campanula iredinm). Spikes of handsome bell-shaped flowers.

Canary Bird Vine. A rapid-growing climber witl finely cut foliage and canary-colored

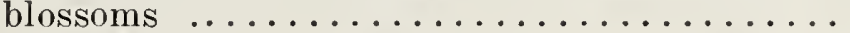

Candytuft. Showy branching plants; fine for

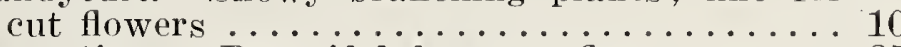

Carnations. Beautiful fragrant flowers...... . . 5

Castor-0il Rean. Picturesque foliage; stately growth; brilliantly colored fruit.......... 10 Celosia (Cockscomb). Odd, decorative plants that are easily grown and very interesting. 10

Convolvulus (Morning-Glory). Rapid-growing climbers bearing bright-colored flowers..... 1

Coreopsis. See Calliopsis.

Cornflower. Flowers of enormous size, fragrant and of charming colors...........10

Cosmos. Tall-growing, profuse-blooming; large flowers .......................... 10

Delphinim (Larkspur). Spikes of liandsome

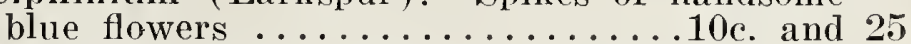

Dianthus (Garden Pinks). Commence flowering early and continue throughout the season $10 \mathrm{c}$. and 25

Eschscholtzia (California Poppy). Interesting bluish green foliage and yellow and orange

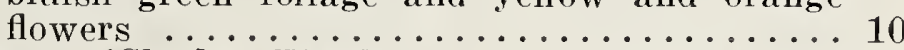

Four o'Clocks. Handsome, free-flowering, fragrant old favorites ............... 10 Gaillardia. Showy and free blooming, with flowers of large size...............10

Gourds. Vines that grow rapidly and bear odd-shaped fruits ..................10

Ielianthus (Sunflower). Among the showiest of our garden plants...........5c and 10

Hollyhocks. Stately reminders of the glories of Grandmother's garden .............. 10

Kudzu Vine. Rapid-growing climber, reaching up 30 to 50 feet in a season......10c. and 25

Lantana. Fine for bedding or pot culture... 10

Marigold. Furnishes a striking display of yellow, orange and brown flowers....5c. and 10

Mignonette. No other flower is so generally grown for its fragrance........10c. and 25

Moonflower. Climber that grows quickly and bears large wlite flowers............. 10

Myosotis (Forget-me-not). Dainty little flow ers of white or blue. An old favorite.... 10

Nasturtium, Tall and Dwarf. Offer a lavish display of vari-colored flowers..... Oz. 25c... 10

Pansies. Charming lace-like flowers in many colors .............................. and 50

Petunia, Single and Double. No better plants for beds, masses, borders, window- or porchboxes. Richly colored flowers....10c. and 25

Phlox. Dazzling in effect, especially when sown in masses of contrasting colors........10

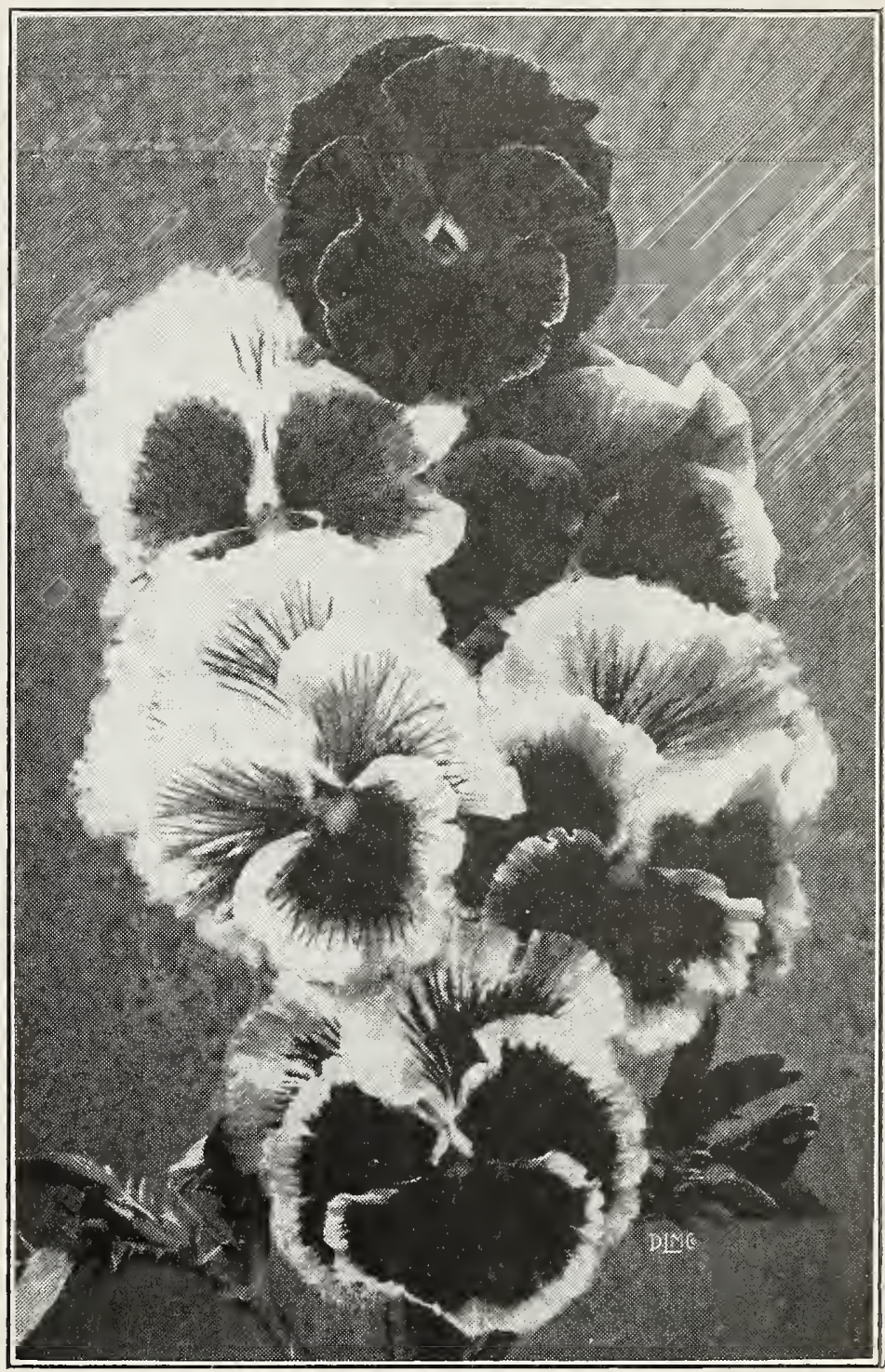

Pansies

Poppies. Flaming masses of color and airy Pkt. gracefulness characterize these plants....\$0 10

Portulacas. Unrivaled for brilliancy among

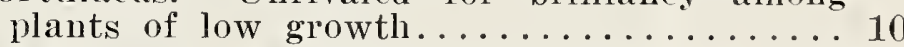

Salpiglossis. Funnel-shaped flowers having dark veins on a ground that varies from white to crimson, yellow, orange, etc.......... 10

Scabiosa (Mourning Bride). Long-stemmed flower's through summer until frost; last a long time when cut..............

Schizanthus. Elegant foliage plants witl masses of flowers in a wide range of colors.. 10 Snapdragon. See Antirrhinum.

Stocks. Fine leaves, beautiful and fragrant flowers

Sunflower. See Helianthus.

Swect Peas. Too well known to need description All the finest varieties. Oz. 25c., 1/4 1b. $75 \% 10$ Mixed. A choice assortment that will give ia splendid variety of color and forms.. Lb. $\$ 1$

Swcet William. Produces large heads of be: tifully colored, sweet-scented flowers..

Verbcira. Plauts bloom from early summei until frost. Fine for beds, borders, windowboxes ...................10 and Zinnias. Few flowers are so easily grown rom seed or bloom so freely ............... 


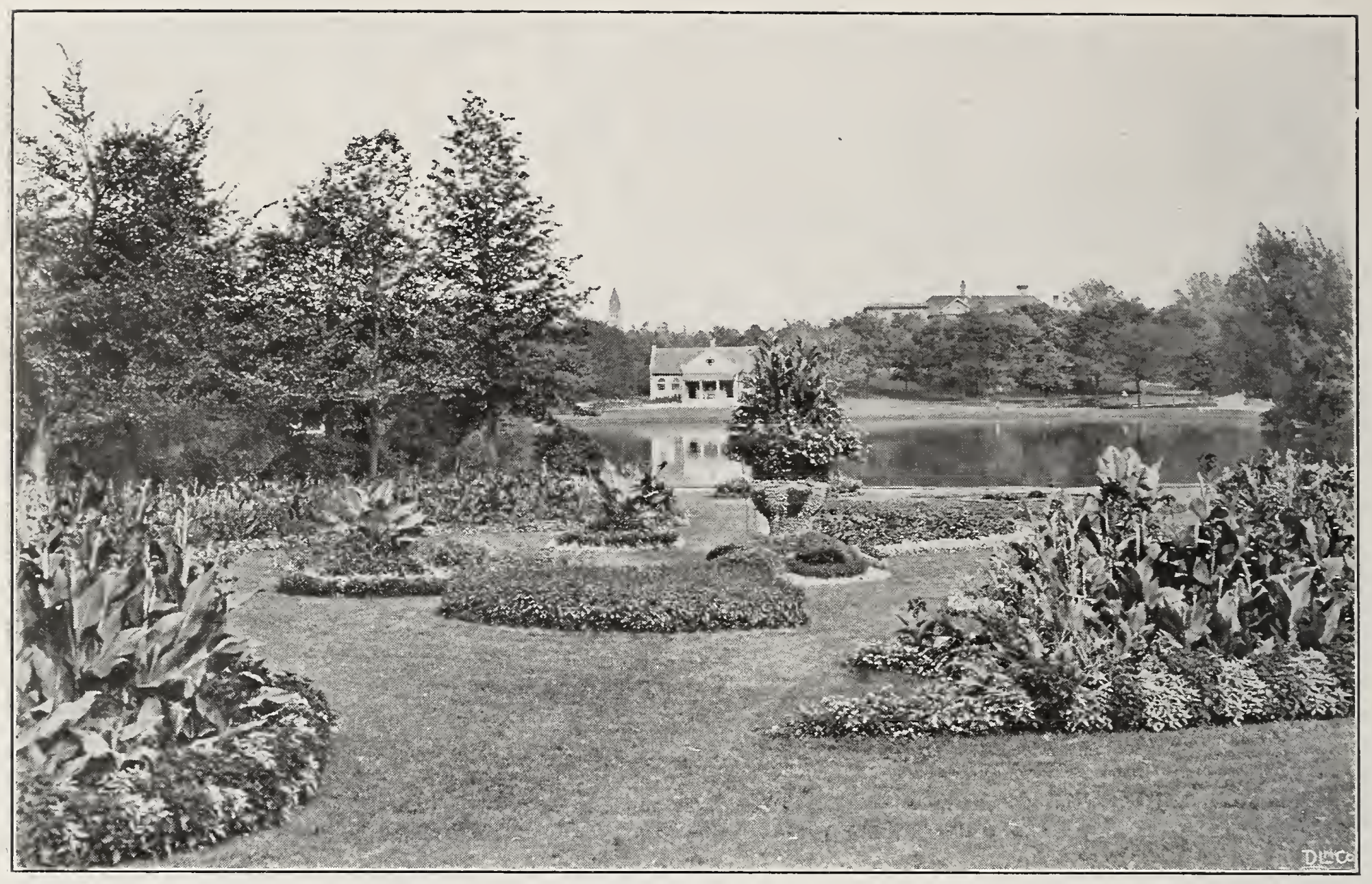

\section{Bedding Plants}

For those who do not have the time or the inclination to grow plants from seed for bed or border, we offer below some of the farorite subjects for that purpose-plants that are rich in foliage and flower effects and furnish variety even as to form, for there are trailel's, low-growing, tall-growing and high-climbing plants anong those listed. Write us for prices before buying elsewhere.

Ageratum. Free-flowering plant that gives a delightful blue note to the bed; single heads will remain fresh and perfect for a month in the open air. Thrives in any good garden soil.

Aster. The queen of autumn annuals, making a splendid showing in the border or planted in masses of harmonizing shades.

Begonia. Handsome in foliage and bearing great quantities of lovely flowers of wax-like texture and delicate shades.

Calarlium. Effective for massing and bordering in connection with subtropical effects, and equally desirable for lawn planting.

Canna. 'The most popular' and most magnificent of all summer-blooming plants for bedding and massing purposes. Attractive foliage and large flowers of great beauty. Many splendid varieties have been introduced within recent years that have brought these magnificent plants to the front as most effective specimens for the bed or border.

Colora. Excellent r limber for out-of-loors p pretty foliage and large, bell-shaped flower's that open a clear green but turn to a lovely purplish blue. Coleus. Old-time favorites for bedding, with handsomely colored foliage. The variegations and mottlings of some of the varieties are quite berond description.

haisies. Charming little plants for early spring bedding, as they are a mass of bloom soon after iv $\mathrm{rm}$ weather sets in.

We have a large variety of hardy plants in clumps that will bloom the first year; also LILY bulbs, GL

\section{Window Boxes}

To be successful with window boxes, have (1) proper soil; (2) a selection of plants and rines that will harmonize $h$ the surroundings: (3) good care-plenty of water in dry weather, overhead and at the roots; (4) after they e bee planted six weeks, give top-dressing of sheep manure or a nixture of fine bonemeal and soil spread er thre p of the ground, just covering the surface. I would recommend this dressing at least three times during ne. S r mer. 


\section{Auto-Spray Pumps}

No other style of sprayer will do such a variety of work, and do it so well. We recommend it for trees, shrubs and vines, greenhouses, poultry-houses, hospitals and stables for disinfectants, for sheep and cattle dip and cattle fly oils. It may be used where any bucket or knapsack sprayer can be used and with much more satisfaction. Even those who have commercial orchards and large power sprayers need the Auto-Spray No. 1 for small work.

No. 1A. Brass tank, with stop-cock.

No. 1B. Brass tank, with auto-pop

No. 1C. Galvanized tank, with stop-cock

No. 1D. Galvanized tank, with auto-pop.

Auto-pop nozzle, with hose and connections

Auto pop nozzle .......................

Extension pipe
Brass strainer.

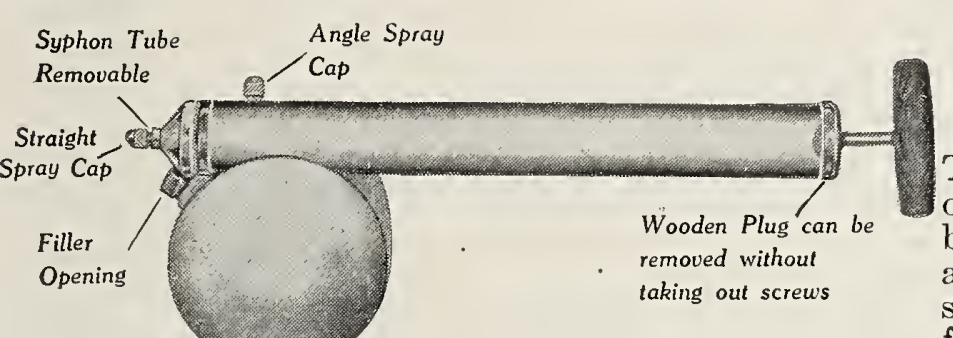

\section{Fertilizers}

Bone Veal. Pure bone dust, one of the most desirable fertilizers. The benefits from it are quickly derived and very lasting. $5 \mathrm{lbs}$. 50c., 10 lbs. S5̃c. 25 lbs. $\$ 1.65$. 50 lbs. $\$ 3.00,100$ lbs. $\$ 5.00$. For larger quantities. write for prices.

Lawn Fertilizer. Special for top-dressing lawns. 5 lbs. $40 \mathrm{c} . .10$ lbs. $70 \mathrm{c} . .25$ lbs. $\$ 1.40$, 50 lbs. $\$ 2.25,100$ lbs. $\$ 4.00$. For larger quantities, write for prices.

Ground Bone. Is of value for garden crops, fruit trees, grape-vines, etc. 10 lbs. S.jc. $2.5 \mathrm{lbs}$ $\$ 1.65,50$ lbs. $\$ 2.75,100$ lbs. $\$ 4.75$. For larger quantities, write for prices.

Alphano Himus. Used for top-dressings and for all general purposes. $25 \mathrm{lbs} .95 \mathrm{c} . .50 \mathrm{lbs} . \$ 1.65,100 \mathrm{lb}$; $\$ 2.40$. For larger quantities, write for prices.

Canadian Hardwood Aslies, Clay's Fertilizers, Nitrate of Solla, and Agricultural Salt are also carried in our supplies.

\section{Insecticides}

Aphis Punk. The most convenient way of applying an insecticide ever ret derised. Per case, 1 doz. air-tight containers. 1 doz sheets each, $\$ 8.50 ; 1$ doz sheets in air-tight package, $75 \mathrm{c}$.

Aphine. Will kill plant lice of everv species. Gill $25 c$. 1/2 pt. 40c.. pt. 65c., qt. $\$ 1.00$, gal. $\$ 3.00$.

Ant Destroyer. A non-poisonous powder. Box 15c., 1/4 lb. 25 c., $1 / 2$ lb. 40c., lb. 75 c.

Arsenate of Lead, Paste, Key Brand. For caterpillars, chewing insects, fruit flies and codling moth. Lb. $45 \mathrm{c} .5$ lbs. $\$ 2.00,10 \mathrm{lbs} . \$ 3.50,25$ lbs. $\$ 6.50,50$ lbs. $\$ 12.50,100$ lbs. $\$ 24.00$.

Arsenate of Lead, Powdered, Key Brand. Dilute one pound to fifty gallons of water. Lb, 75c. 5 lbs. $\$ 3.25,10$ lbs. $\$ 5.50,25$ lbs. $\$ 12.50$.

Bordeaux Mixture, Paste, Key Brand. For blight, mildew, rust and fungous discases. Lb. $40 \mathrm{c}$. 5 lbs. $\$ 2.00,10 \mathrm{lbs} . \$ 3.50$.

Bordeaux Mixture, Powder, Key Brand. Used same as bordeaux mixture. also for dusting dry. Lb. 55c., 5 lbs. $\$ 2.50 .25 \mathrm{lbs} . \$ 8.00$.

Black Leaf 40. An effective insecticide for sucking insects snch as plant lice, aphis, red spider, leaf hopper, thrips. $1 \mathrm{oz}$. bottle $25 \mathrm{c} .{ }^{1 / 6} \mathrm{lb}$. tin $\$ 1.00$.

Fungine. An infallible remedy for mildew and other fungous diseases. Pt. $65 \mathrm{c} .$, qt. $\$ 1.10$, gal. $\$ 3.50$.

Hellebore Powder. For rose-slugs, currant-worms, etc. Dust on with bellows while the foliage is moist. $1 / 4$ lb. 20c., 1/2 lb. 40c., lb. $75 \mathrm{c} ., 5 \mathrm{lbs}$ $\$ 3.50$.

\section{Auto-Spray} No. 25

The Auto-Spray No. 25 operates continuously on both the up and down stroke and throws a fine, misty

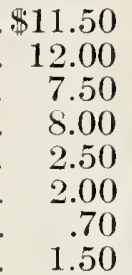
spray. Two spray caps, one straight and one at an angle for under the leaves. Capacity 8 quarts. No. 25B, Galvanized tank, $\$ 1.35$ each; No. $25 \mathrm{C}$, Brass tank, $\$ 1.75$ each.

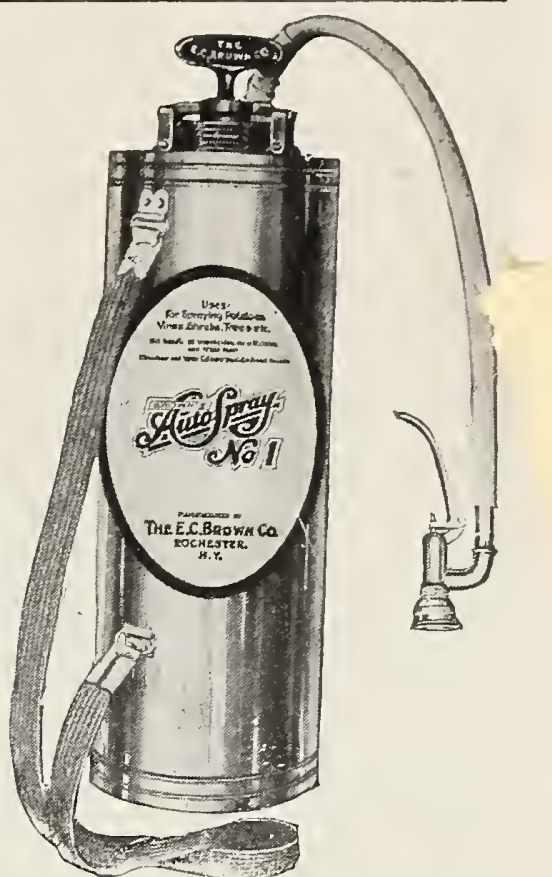

of Fertilizers are subject

to market changes.

Potato Manure. High grade; prepared especially for the potato crop; doubles the vield. $10 \mathrm{lbs}$. 65c.. 25 lbs. $\$ 1.40,50$ lbs. $\$ 2.5 .100$ lbs. $\$ 4.10$. For larger quantities, write for prices.

Vegetable compound. The fertilizer that always produces a good healthy crop of regetables. 5 lbs. $50 c . .10$ lbs. 85 c.. 25 lbs. $\$ 1.65,50$ lbs. $\$ 3.00,100$ lbs. $\$ 5.00$.

Agricultural Lime. Useful for lawns. regetables, gardens and sour lands. 25 lbs. 60c., 50 lbs. $\$ 1.00,100$ lbs. $\$ 1.85 . \quad$ For larger quantities, write for prices.

Pulverized Slicep Manure. A rich, pure and natural manure, suited for all garden purposes. There is scarcely any fertilizer equal to sheep manure for lawns. flowers, fruit and vegetables. 5 lbs. $50 \mathrm{c} ., 10$ lbs. S5c., 25 lbs. $\$ 1.50$, 50 lbs. $\$ 2.50,100$ lbs. $\$ 4.00$.

\section{of Insecticides are subject}

to market changes.

Lime Sulphur Solution. For spraying fruit trees. Gal. \$1.25. 5 gals. \$3.75.

Vico-Fume Paper. Fxtra strong. 24 sheets $\$ 1.25$ 144 sheets $\$ 5.00$, 288 sheets $\$ 9.50$.

Nikoteen. A thorough exterminator of mealy-bug, thrips. lice and all insects affecting plant life. 13 ozs, $60 c$. lb $\$ 2.55$, S-lb. tins $\$ 14.00$.

Paris Greell. For potato bugs, etc. $1 / 4 \mathrm{lb}$. $20 \mathrm{c}$. $1 \%$ lb. 40c.. lb. $75 \mathrm{c}$.

Pyox, Bowker's. Kills all leaf-eating insects, and prevents blights and fungous troubles. 5 lbs. $\$ 2.00,10$ lbs. $\$ 3.50,25$ lbs. $\$ 650,100$ lbs. $\$ 24$ Scalecirle. 1-gal, can $\$ 1.65,5$ gals, $\$ 6,50,10 \mathrm{mals}$ $\$ 12.00$. 30 gals. $\$ 27.00$, 50 gals. $\$ 45.00$.

Slug-Shot. Destroys all insects injurions to plants vegetables and fruits of all kinds. Lb cartons 25c. 5-lb. pkg. 75c., 10 lbs. \$1.50, 125-lb. keg $\$ 14.00$.

Sulphur, Powdered. A staple preventive of mildew on grapes, roses, etc Lb. 15̌c., 10 lbs, $\$ 1.00$ $25 \mathrm{lbs}$. and over, 9c. per $1 \mathrm{~b}$.

Tree Tamglefoot. Applied directly to the One pound will make a band - to $S$ font Lb. ran 50c.. 3 lbs. \$1.45. 10 lbi $\$ 8.75$.

Tobacco Dust. Destroys rose lice. turnip fleas, etc Lb. $15 \mathrm{c}$. $5 \mathrm{lbs}$. soc.. 100 lbs. $\$ 6.00$.

Weed Killer. Gal \$2.00. 5 gals. $\$ \$ .00$

Whale-Oil Soap wilh Tobaceo. Kil sucking insects on trees, shrubs, pli and roses. Lb. 30c.. 5 lbs. $\$ 1.40,25$ 


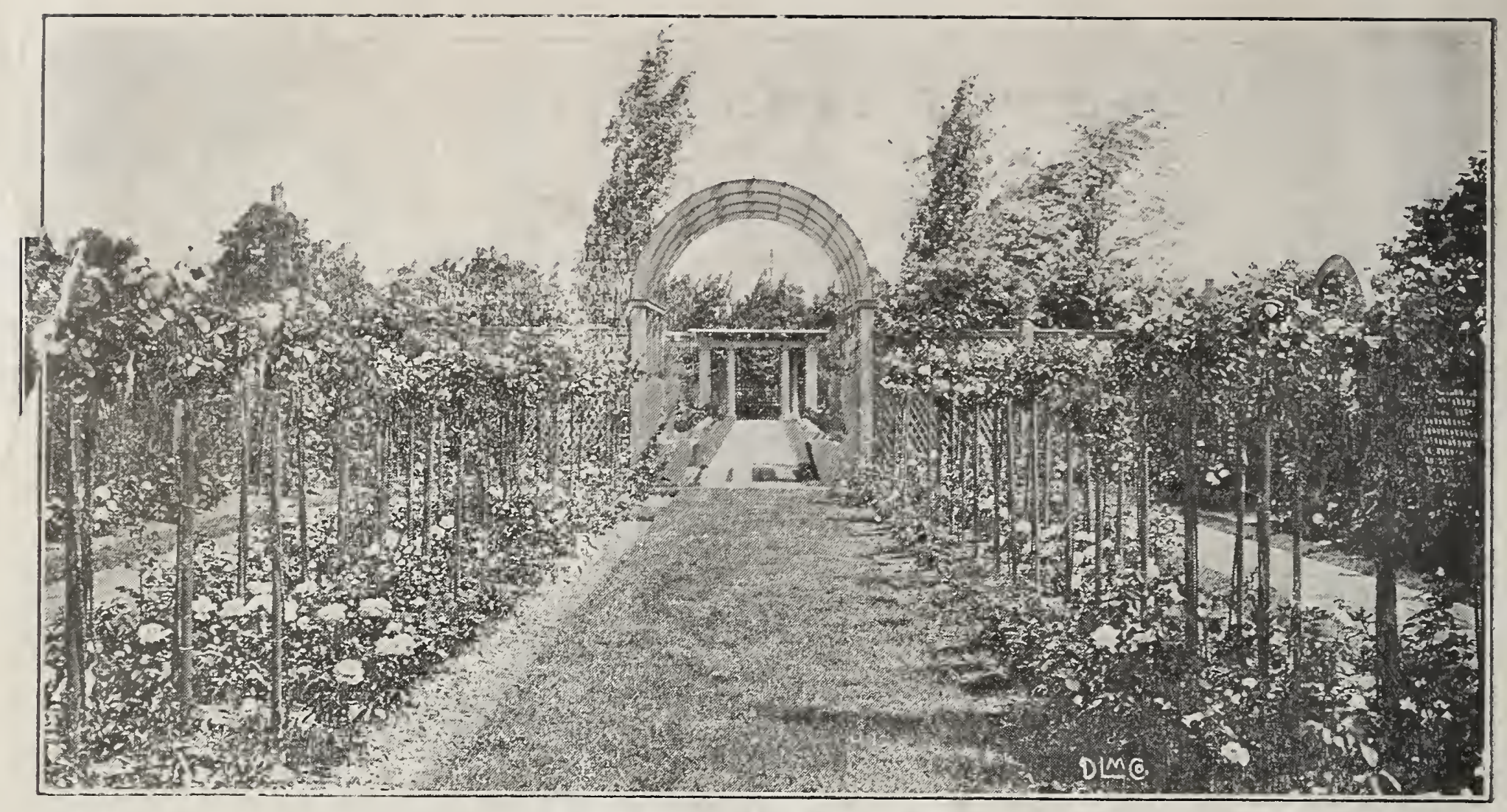

[FRED EASTMAN ROSE GARDEN

\section{The Joy of Growing Roses}

First, you ask us to send you a selection of the best varieties of Hybrid Tea Rosesthe class that offers the richest colorings and the greatest profusion of bloom. Second, you choose a location in your garden where there is good, deep, rich soil. If you don't have such a place, make it; dig out the soil to a depth of 2 to $2 \frac{1}{2}$ feet and fill in with good top-soil and well-rotted cow manure. Third, when the plants arrive, you dig holes large enough to give ample room for the roots and plant I 8 inches apart each way. Fourth, cultivate frequently during the Summer and spray occasionally with Bordeaux Mixture to discourage insects and mildew. Fifth, when the plants begin to bloom you make frequent visits to your Rose bed, admire their beauty and revel in their fragrance, and if sorneone is sick in your neighborhood, cut a few of your choicest blooms and send them to the sick room. They will be the finest kind of "first aid" to any medicine, and in the expression of thankfulness that comes back to you will lie a new joy for you in Rose growing.

We have a fine stock of varieties in the prettiest shades-light, medium and dark pink, yellow, bronze, cherry, red, crimson and white, all well started in pots and ready to take a conspicuous place in your garden.

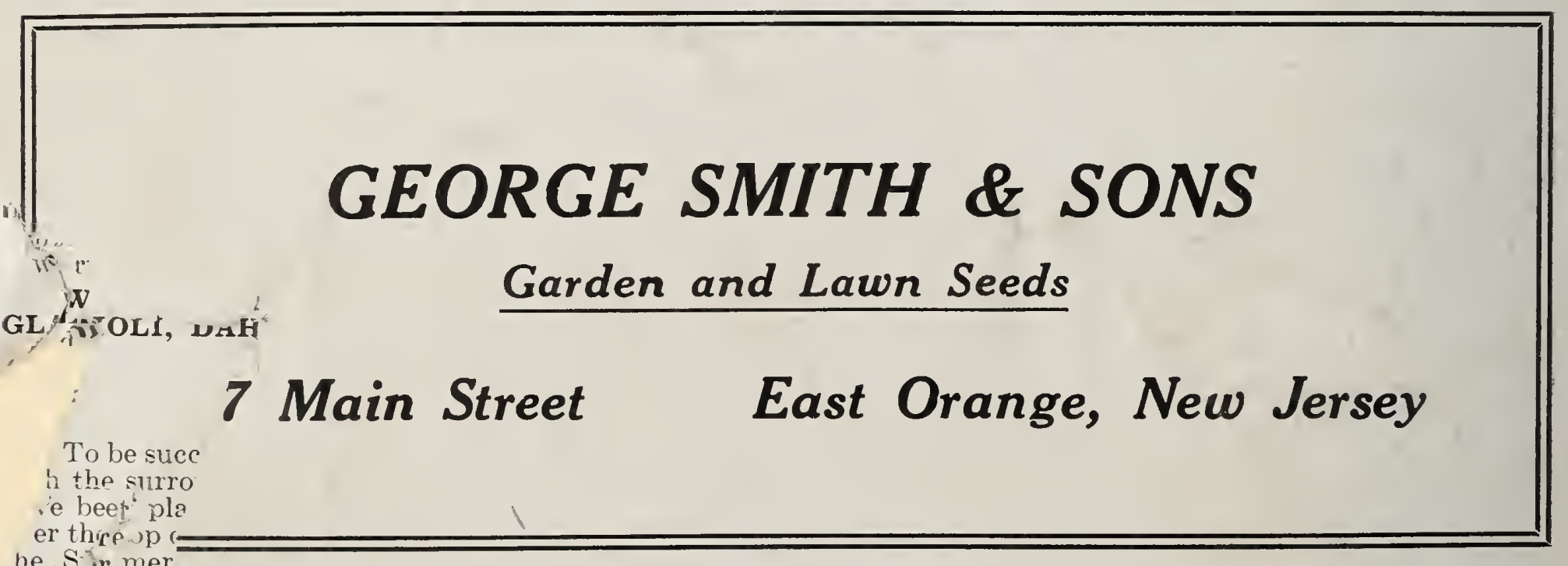

he S-mer 